Portland State University

PDXScholar

7-6-2021

\title{
Testing Functional Variation in Thermal Properties for Antarctic Mosses
}

Andrew Forrest Clements

Portland State University

Follow this and additional works at: https://pdxscholar.library.pdx.edu/open_access_etds

Part of the Biology Commons

Let us know how access to this document benefits you.

\section{Recommended Citation}

Clements, Andrew Forrest, "Testing Functional Variation in Thermal Properties for Antarctic Mosses" (2021). Dissertations and Theses. Paper 5721.

https://doi.org/10.15760/etd.7594

This Thesis is brought to you for free and open access. It has been accepted for inclusion in Dissertations and Theses by an authorized administrator of PDXScholar. Please contact us if we can make this document more accessible: pdxscholar@pdx.edu. 
Testing Functional Variation in Thermal Properties

for Antarctic Mosses

by

\section{Andrew Forrest Clements}

A thesis submitted in partial fulfillment of the requirements for the degree of

\section{Master of Science in \\ Biology}

Thesis Committee:

Sarah M. Eppley, Chair

Todd N. Rosenstiel

Mitchell B. Cruzan

Portland State University

2021 
(C) 2021 Andrew Forrest Clements 


\begin{abstract}
As the maritime Antarctic ecosystem continues to warm, glacial retreat will further expose subterranean permafrost to warmer conditions. One of the most visible changes in the ecosystem is the colonization of the new ice-free areas by bryophytes, particularly mosses. These bryophytes are having important effects on terrestrial thermal properties, but little is known about differences among Antarctic moss species in their thermal properties. Here, I measured the thermal conductivity, specific heat capacity, and the water content of moss species on King George Island to understand the insulation ability of Antarctic mosses, Polytrichastrum alpinum, Sanionia georgicouncinata, Chorisodontium aciphyllum, Andreaea gainii, and Syntrichia filaris. I found that $C$. aciphyllum consistently showed the highest thermal conductivity with little drop off as plants dried over time. S. georgicouncinata and S. filaris both showed a mid-level thermal conductivity with a greater drop off over time than $C$. aciphyllum, while $P$. alpinum and A. gainii both had a significantly lower thermal conductivity. These data mirror what was found in the percent water content remaining over time. Morphologically, plants in low nitrogen sites were less thick and dense than in high nitrogen sites, yet this resulted in higher rather than lower thermal conductivity. In low nitrogen sites, I found that plants had higher thermal conductivity and lower overall relative water content but retained that water longer. These data suggest that Antarctic mosses fall into functional groups based largely on their canopy morphology and thermal properties, and that elevated nitrogen has a significant enough effect on their canopy morphology to impact their thermal properties and water content. This study investigates
\end{abstract}


how species composition, functional grouping, and changing nutrient dynamics affect the role bryophytes play in the temperature dynamics of the maritime Antarctic system. This understanding will aid in making educated predictions regarding the future of the permafrost layer and ecosystem structure under continued warming. 


\section{ACKNOWLEDGMENTS}

It is important that I express my gratitude and appreciation to those individuals who have helped to make this research and my graduate education possible. I first want to thank my advisors, Dr. Sarah Eppley and Dr. Todd Rosenstiel for their mentorship, guidance, and patience throughout my graduate experience, and for breaking me into the world of plant research in the first place. I also want to thank Dr. Mitchell Cruzan for his help with developing and troubleshooting my experimental design. I have had the great privilege to work with a multitude of wonderful colleagues over the last few years whom I would like to acknowledge as well. Dr. Hannah Prather and Dr. Matthew Chmielewski were instrumental in many aspects of my graduate progress, notably collecting the moss samples along with Dr. Todd Rosenstiel for this project, as well as being prime examples of researchers and teachers for me to follow. In addition, this research was completed with assistance from Danlyn Brennan, Eve Spruell, and Sara Herrejon Chavez. I also would like to thank my colleagues, Scott Kiel, Erin Davis, Stef Steele, Lillian Raley, Dr. Timea Deakova, and Caitlin Maraist for their help and support throughout my graduate journey. Finally, I want to thank my family for their unconditional encouragement, caring words, and willingness to listen. Their emotional support, late night phone calls, and unshakable optimism are things that I never want to take for granted.

All sample collection in this research was completed in cooperation with Dr. Angelica Casanova-Katny and the Chilean Antarctic Institute (INACH). This research was made possible through funding from the National Science Foundation. 


\section{TABLE OF CONTENTS}

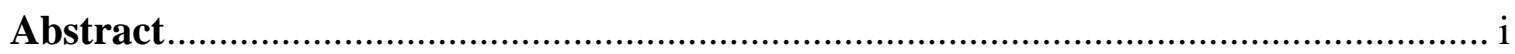

Acknowledgements ....................................................................................... ii

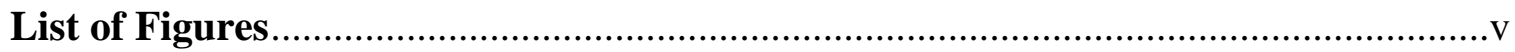

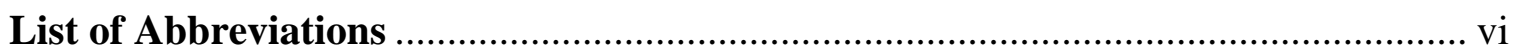

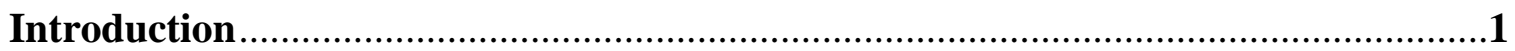

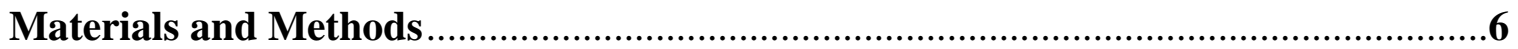

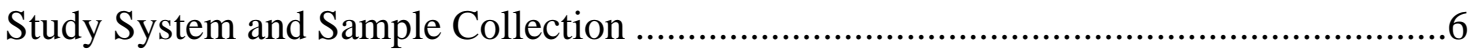

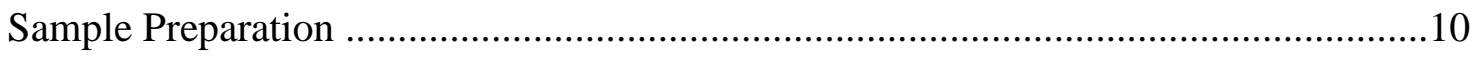

Laboratory Measures of Thermal Properties and Water Content ..................................11

Laboratory Measures of Canopy Morphology ..............................................................12

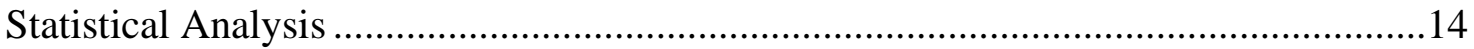

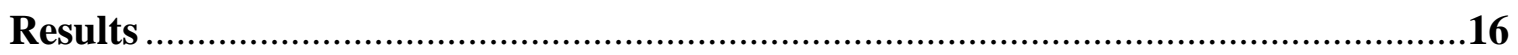

Water Content and Thermal Conductivity Across Five Moss Species ..........................16

Quantifying Tissue Nitrogen Content ………………............................................

Water Content and Thermal Conductivity Across Two Sites and Three Moss Species 18

Moss Canopy Morphology Across Two Sites and Three Species .................................20

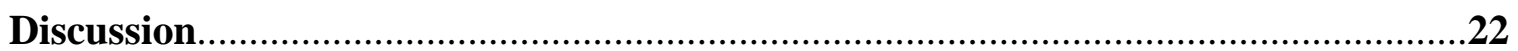

Water Content and Thermal Conductivity .............................................................24

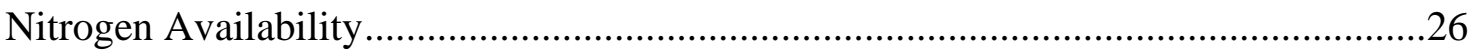

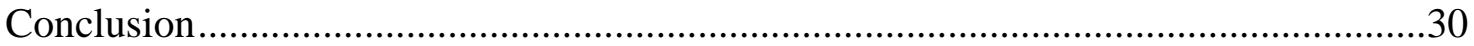

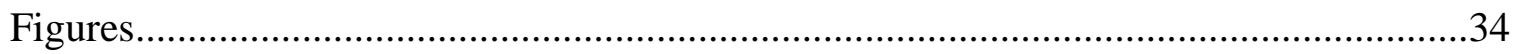

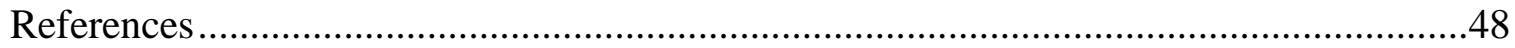




\section{TABLE OF FIGURES}

Figure 1: Map of the Fildes Peninsula, King George Island

Figure 2: Map of Ardley Island

Figure 3: Percent water mass remaining (\%) in the moss canopy over seven days for five moss species from the Fildes Peninsula

Figure 4: Relative water mass in the moss canopy (\%) over seven days for five moss species from the Fildes Peninsula

Figure 5: Thermal conductivity $\left(\mathrm{W}\left(\mathrm{m}^{*} \mathrm{~K}\right)^{-1}\right)$ over seven days for five moss species from the Fildes Peninsula

Figure 6: Specific heat capacity $\left(\mathrm{J}\left(\mathrm{kg}^{*} \mathrm{~K}\right)^{-1}\right)$ over seven days for five moss species from the Fildes Peninsula

Figure 7: Tissue nitrogen content (\%) in mosses from four sites on Ardley Island

Figure 8: Percent water mass remaining $(\%)$ in the moss canopy over seven days in two sites with different nitrogen concentrations on Ardley Island

Figure 9: Relative water mass in the moss canopy (\%) over seven days in two sites with different nitrogen concentrations on Ardley Island

Figure 10: Thermal conductivity $\left(\mathrm{W}\left(\mathrm{m}^{*} \mathrm{~K}\right)^{-1}\right)$ over seven days in two sites with different nitrogen concentrations on Ardley Island

Figure 11: Specific heat capacity $\left(\mathrm{J}\left(\mathrm{kg}^{*} \mathrm{~K}\right)^{-1}\right)$ over seven days in two sites with different nitrogen concentrations on Ardley Island

Figure 12: Hydrated gametophyte width $(\mathrm{mm})$ in three moss species from two sites with different nitrogen concentrations on Ardley Island

Figure 13: Moss canopy thickness $(\mathrm{mm})$ in three moss species from two sites with different nitrogen concentrations on Ardley Island

Figure 14: Gametophyte density $\left(\right.$ per $\mathrm{cm}^{2}$ ) in three moss species from two sites with different nitrogen concentrations on Ardley Island 


\section{LIST OF ABBREVIATIONS}

$\begin{array}{ll}\text { AF/ARFR } & \text { Ardley Far moss collection site } \\ \text { AND } & \text { Andreaea gainii } \\ \text { CHORI } & \text { Chorisodontium aciphyllum } \\ \text { KGI } & \text { King George Island } \\ \text { LH } & \text { Lighthouse moss collection site } \\ \text { PN } & \text { Penguin moss collection site } \\ \text { POLY } & \text { Polytrichastrum alpinum } \\ \text { RF } & \text { Refugio moss collection site } \\ \text { SAN } & \text { Sanionia georgicouncinata } \\ \text { SYN } & \text { Syntrichia filaris } \\ \text { WAP } & \text { Western Antarctic Peninsula }\end{array}$




\section{INTRODUCTION}

Global warming is affecting ecosystems across the planet (Arndt et al. 2013, Nerem et al. 2018, Velicogna et al. 2020, De Frenne et al. 2021). While the effects are being felt in nearly every system, the Western Antarctic Peninsula (WAP) and the Scotia Arc have experienced greater than average warming and resulting environmental changes (Bracegirdle et al., 2008; Bromwich et al., 2013; Green et al., 2015). Drastic glacial recession (Cook et al., 2005; Vaughan \& Doake, 1996) has led to rapid ecosystem shifts exposing the substrate below and increasing the availability of ice-free areas for plant colonization in these regions. Aside from two species of flowering plants (Rudolph 1965), lichens and bryophytes—specifically mosses and liverworts—are the dominant plants of Antarctica and thus have been the primary colonizers of newly ice-free Antarctic land (Favero-Longo et al. 2012, Olech and Słaby 2016). This greening is fundamentally changing the ecosystem structure in terrestrial and maritime Antarctica (Amesbury et al. 2017) not just in plant species composition, but in function as well (Fountain et al. 2016, Prather et al. 2019). Although the specific details underlying the ecosystem feedback effects of colonizer species have been well studied in arctic and alpine glacial systems (Bardgett and Walker 2004, Cannone et al. 2008, Knelman et al. 2012, Castle et al. 2016) and studied to some degree in the Antarctic system (Strauss et al. 2009, Boy et al. 2016), the implications of these feedbacks in the greening and rapidly warming Antarctic system are poorly understood. Soil nitrogen concentration and thermal changes following glacial retreat are notable examples of these systemic feedbacks (Thomazini et al. 2015, Schmidt et al. 2016). 
As mosses and lichens colonize ice-free areas after glacial retreat, they begin to alter the structure of these new habitats. Water content in the soil and plant canopy, presence of chemical nutrients in the soil, and invertebrate fauna are significant factors in this transformation (Eviner and Chapin III 2003, Bokhorst and Convey 2016), but the greater ecosystem ramifications of this greening process are not yet clear. Bryophyte species differ significantly in morphology and physiology (Hespanhol et al., 2014; Proctor \& Smirnoff, 2015), which affect traits such as nutrient availability and thermal effects on the soil (Gavazov et al. 2010, Soudzilovskaia et al. 2013, Ball and Virginia 2014). These functional traits become valuable indicators for how changing bryophyte biodiversity will affect the ecosystem function-i.e., how water is stored in the soil and biotic layer (Beringer et al., 2001) and how the soil temperature is regulated (Gornall et al., 2007). Soil temperature is a key factor in many ecosystem functions especially in cold biomes (Chapin et al. 1995). Activities in soil microbes, such as bacteria and fungi, as well as vascular plants are significantly limited by cold temperatures in the soil (Lloyd and Taylor 1994, Wallenstein et al. 2009). The rapid warming in maritime Antarctica will certainly affect the activity and function of these systems; however, the plant colonization of soil post glacial retreat makes these effects difficult to predict. It has been shown that plant cover, especially plant cover with more of a cushion-like morphology, reduces diurnal temperature fluctuations in cold biomes, helping to stabilize these more temperature sensitive systems (Kleier and Rundel 2009). In addition, bryophytes, specifically mosses, are known to alter soil temperature enough to play a role in controlling ecosystem functions (Gornall et al. 2007, Cannone and Guglielmin 2009, Soudzilovskaia et al. 2013), although the role of vegetation in soil temperature dynamics 
in Antarctica is poorly understood. Temperature regulation of the soil by mosses could be a vital trait for maintaining the permafrost found below ground in much of maritime Antarctica (Porada et al. 2016). These large subterranean ice banks store massive amounts of carbon compounds that have not yet decomposed (Lepane et al. 2018, Samui et al. 2020). However, rapid melting of the snow and ice currently offering thermal protection to these stores would accelerate this melting and decomposition, releasing this carbon into the atmosphere perpetuating a positive feedback loop (Kleinen \& Brovkin, 2018; Potapowicz et al., 2018).

Many studies have been conducted focused on the effects of warming on Antarctic plants across the continent, often with contrary results among sites (Bokhorst et al., 2007; Day et al., 2008; Kennedy, 1995; Shortlidge et al., 2017). With over 100 moss species present in Antarctica, species-specific effects based on morphology are likely. The morphological and physiology traits can vary greatly and allow the mosses to serve diverse functions in their ecosystems (Rice et al. 2008, Fan et al. 2020, Laine et al. 2021). These species-specific traits can affect the soil nutrient concentrations, thermal regulation of the soil, and fluctuations in water regimes in their environments very differently (Cornelissen et al., 2007). Although these species-specific effects on the ecosystem functions have been recognized, the morphological, physiological, and functional traits of the moss species driving these effects are still unclear (Smith et al., 2015; Turetsky et al., 2012). In addition to the species-specific traits, abiotic factors in the environment, such as the presence of elevated nitrogen levels, have been shown to cause changes in moss morphology (Manninen et al. 2011). Since minute differences in species-specific moss 
morphologies can have profound effects on their ecosystem function, changes due to elevated nitrogen could potentially also significantly affect these ecosystem traits, specifically water holding capacity and thermal regulation of the soil (Rice et al. 2001, Li et al. 2021). Understanding how differences in moss morphologies among species, as well as variations within species, can impact the thermal and water regimes in maritime Antarctica would be valuable for predicting ecosystem shifts post glacial retreat and understanding the roles that colonizing mosses play in this unique and rapidly developing ecosystem.

In this study, I tested the hypothesis that Antarctic moss species differ significantly in their thermal properties and fall into different functional categories with respect to these thermal properties. To test this hypothesis, I measured water holding capacity, drying rate, thermal properties, and structural morphology in Antarctic moss species of varying functional morphology. These traits were emphasized because of the implications for permafrost insulation (Stoy et al. 2012) and because moss species in the northern hemisphere have been found to differ significantly in many of these traits (Soudzilovskaia et al. 2013). In addition, these traits were also contrasted between mosses grown in high nitrogen conditions and low nitrogen conditions to determine whether the morphological effects caused by elevated nitrogen were great enough to impact their insulation ability and water dynamics.

This study was conducted on King George Island (KGI), in the South Shetland Islands. This island has large amounts of ice-free land and a diverse flora. Although climate change is a widespread issue in Antarctica, some of the most profound effects are 
being observed on KGI and on the near Western Antarctic Peninsula (Turner et al. 2014); due to the extensive glacial retreat and melt-off of surface ice in these areas, they host the greatest plant biodiversity in Antarctica (Ochyra et al. 2008). I conducted this study examining thermal properties and their relationship to nitrogen availability on five common moss species, Polytrichastrum alpinum, Sanionia georgicouncinata, Chorisodontium aciphyllum, Andreaea gainii, and Syntrichia filaris from KGI.

Understanding the thermal properties of these dominant plant species in Antarctica can help to determine which of these plant traits are the primary drivers of ecosystem changes post glacial retreat and how they could potentially be used as predictors for vegetation shifts in Antarctica due to ongoing warming (Pearson et al. 2013) in the same way ecological feedbacks are often used to accurately predict the effects of widespread climate change (Van Nes et al. 2015). 


\section{MATERIALS AND METHODS}

\section{Study System and Sample Collections}

This study was focused exclusively on King George Island (KGI), the largest of the South Shetland Islands. Much of its ecology is maritime and it has a large amount of ice-free land around its coasts. My sampling sites are located largely on the Fildes Peninsula and Ardley Island near the Chilean Escudero Base $\left(62.201382^{\circ} \mathrm{S}\right.$,

$58.962358^{\circ} \mathrm{W}$ ) (Fig. 1). The area around this study site is near devoid of ground ice in the summer and has many large moss cushions made up of multiple species. While KGI does have a high biodiversity of mosses, the area around these sites is dominated by two moss species, Polytrichastrum alpinum (Polytrichaceae) and Sanionia georgicouncinata (Amblystegiaceae). Also, in the area at lesser frequency, are moss species Chorisodontium aciphyllum (Dicranaceae), Andreaea gainii (Andreaeaceaea), and Syntrichia filaris (Pottiaceaea). I focused my research on these five species of mosses on KGI.

P. alpinum is a common moss in Antarctic and Southern Ocean regions with a particularly broad distribution along the Western Antarctic Peninsula (WAP) and the South Shetland Islands (Australian Antarctic Division 2021). It is commonly referred to as a "turf moss" meaning it has a more upright structure that tends to collect soil and other substrate material to form thick "turf-like" canopies (Shortlidge et al. 2017). $P$. alpinum has long, robust, pointed leaves on upright gametophytes that spread widely when hydrated (Putzke and Pereira 2001). This species maintains a substantial amount of 
open air within its canopy and is very efficient at draining. P. alpinum is generally dark green to brown in color.

S. georgicouncinata is also among the most dominant moss species found on KGI; together with P. alpinum, they comprise approximate $65 \%$ of the terrestrial vegetation (Prather et al. 2019). Outside of KGI, however, the distribution is much narrower, being restricted largely to the South Shetland Islands (Australian Antarctic Division 2021). This species is commonly referred to as a "feather moss" indicating that its falcate or "sickle-shaped" leaves are arranged in a more linear "frond-like" pattern on gametophytes lay down and tangle together in a plicate arrangement (Putzke and Pereira 2001). The curled shape of the leaves causes them to retain moisture within the canopy. Due to the flat structure of $S$. georgicouncinata, much of the canopy moisture is held in close contact with the substrate. Canopies of S. georgicouncinata are yellow to light green in color.

C. aciphyllum is a relatively common species along the WAP, and the South Shetlands, including KGI (Australian Antarctic Division 2021). It has a particularly high abundance on Ardley Island as well. C. aciphyllum can grow an extraordinarily tall canopy reaching heights up to $3 \mathrm{~m}$ (Allison and Smith 1973, Smith 1981) over thousands of years (Bjorck 1991). Due to the thickness of the canopy, these mosses tend to function similarly to "turf-mosses" like $P$. alpinum, however, because of the dense arrangement of the gametophyte shoots, the canopy does not collect as much turf forming substrate as $P$. alpinum. The majority of the canopy is senescent with only a few millimeters of green 
photosynthetically active tissue at the tips of the canopy and the rest of the canopy eventually become part of the permafrost (Cannone et al. 2017).

A. gainii is another common moss along the WAP and the South Shetland Islands, including KGI (Shortlidge et al. 2017, Australian Antarctic Division 2021). It has been observed to form both dense cushions as well as short turfs. Similar to P. alpinum, A. gainii has pointed leaves arranged radially on upright stems that spread widely when hydrated. However, the leaves of A. gainii are panduriforme in shape and are much smaller. Because of the upright structure, A. gainii also maintains an appreciable amount of empty space in the canopy allowing it to collect substrate like P. alpinum. Unlike the rest of the mosses in this study, A. gainii is generally purplish-brown to black in color (Putzke and Pereira 2001).

S. filaris also has a more restricted distribution but is found among the South Shetland Islands and KGI (British Antarctic Survey 2021) The stems are generally very short with small lanceolate leaves. They form dense cushions with little empty space in the canopy for substrate collection (Putzke and Pereira 2001). They are not "feathermosses" but are more similar in morphology to S. georgicouncinata than the morphology of more traditional "turf-mosses" such as P. alpinum. Canopies of S. filaris are generally a light green to yellow color.

Moss samples used in this study were collected from (KGI) in February of 2016. This location was chosen because of the abundance of terrestrial mosses and the proximity to the Chilean Julio Escudero research base. The first sampling site was located outside the Escudero research base $\left(62.201382^{\circ} \mathrm{S}, 58.962358^{\circ} \mathrm{W}\right)(\mathrm{Fig} .1)$. At this 
site, the five species of moss with distinct morphologies were collected. Polytrichastrum alpinum represented the "turf moss" functional group with more robust, upright ramets and leaves, while Sanionia georgicouncinata represented the "feather moss" functional group with longer more relaxed ramets and curled leaves. The last three species collected, Syntrichia filaris, Andreaea gainii, and Chorisodontium aciphyllum had morphologies that fell somewhere between the two functional groups. For each species, five $2500 \mathrm{~cm}^{2}$ sample locations were chosen and three replicate $2 \mathrm{~cm}$ diameter cores as well as one replicate $36 \mathrm{~cm}^{2}$ patch were sampled from each plot; this resulted in a total of fifteen cores and five $36 \mathrm{~cm}^{2}$ patches for each species. For the replicate cores, core depth was as such that the whole canopy and rhizoid structure was kept intact with as little soil as possible. These cores were transferred to coin envelopes and oven dried at $40^{\circ} \mathrm{C}$. For the $36 \mathrm{~cm}^{2}$ patches, samples were taken down to approximately the soil surface, maintaining an intact canopy. The $36 \mathrm{~cm}^{2}$ patches were transferred to individual paper bags and oven dried at $40^{\circ} \mathrm{C}$.

The second round of sampling came from four separate sites of varying distance from the Gentoo penguin colony on the coast of Ardley Island east of the Fildes Peninsula (Fig. 2). Because of their location with respect to the penguin colony, I hypothesized that they may vary in available soil nitrogen concentrations. One site referred to as Lighthouse $(\mathrm{LH})\left(62.211461^{\circ} \mathrm{S}, 58.927219^{\circ} \mathrm{W}\right)$, because of the proximity to a lighthouse near the penguin colony, served as the high soil nitrogen site since it was the closest to the penguins and was the most affected by the nitrogen input from guano. Sites referred to as Penguin (PN) $\left(62.210692^{\circ} \mathrm{S}, 58.933364^{\circ} \mathrm{W}\right)$ and Refugio (RF) 
$\left(62.210056^{\circ} \mathrm{S}, 58.940747^{\circ} \mathrm{W}\right)$ were second and third respectively in distance from the penguin colony, and a final site, Ardley Far (AF) $\left(62.211906^{\circ} \mathrm{S}, 58.948639^{\circ} \mathrm{W}\right)$, represented the low soil nitrogen site, being the furthest from the penguin colony on the opposite coast. All these sites were sampled in the same manner as the Escudero site, however only three species were collected from these locations, Polytrichastrum alpinum, Sanionia georgicouncinata, Chorisodontium aciphyllum. These species were chosen as they were some of the most abundant species found on Ardley Island. In addition, these species possess very different functional canopy morphologies representative of different functional groups.

Five replicate cores of all three species from each of the Ardley Island collection sites were sent to Cornell University for combustion analysis of tissue nitrogen.

\section{Sample Preparation}

To measure water content, drying rates, and thermal properties of the collected moss samples, acrylic tubes $3 \mathrm{~cm}$ tall and $2 \mathrm{~cm}$ in diameter were constructed with a fine vinyl coated fiberglass mesh affixed to one end of the tube to hold the moss cores and facilitate drainage. Moss samples were then trimmed to the height of the tubes using a straight razor blade. The moss canopy was prioritized when trimming; however, some species of mosses with a shallower canopy, such as $S$. filaris, required a small amount of rhizoid to be retained in order to fill the tubes. All trimmed material was returned to coin envelopes. The trimmed samples were then carefully placed in the acrylic tubes with 
efforts made to disturb the canopy structure and density as little as possible. The tubes and samples were weighed, and the dry mass of the trimmed cores was measured.

\section{Laboratory Measurements of Thermal Properties and Water Content}

To measure the thermal properties of the moss species with respect to their water content, I saturated the mosses in the tubes and measured water content by mass and thermal properties over time, as the moss dried. The mesh drain on each of the tubes was plugged using a rubber barrier on the bottom of the tube. The tubes were then filled with water, submerging as much of the moss samples as possible. The saturation process was monitored for 30 minutes with water being added as needed to keep the tubes full. After 1 hour of saturating, the tubes were moved to a rack elevated $4 \mathrm{~cm}$ above the counter in a cold room at $4{ }^{\circ} \mathrm{C}$ to simulate Antarctic temperatures without allowing the samples to completely freeze. The samples were allowed to cool to temperature for 24 hours.

After the samples had cooled and saturated for 24 hours, the samples were drained one at a time by removing the rubber barrier. Immediately after draining, the samples were weighed and the thermal conductivity $\left(\mathrm{W}(\mathrm{m} * \mathrm{~K})^{-1}\right)$, thermal diffusivity $\left(\mathrm{mm}^{*} \mathrm{~s}^{-2}\right)$, and volumetric heat capacity $\left(\mathrm{J}(\mathrm{kg} * \mathrm{~K})^{-1}\right)$ were measured while still in the cold room using a KD2-Pro Thermal Properties Analyzer by Decagon Devices (accuracy $\pm 10 \%$ ). The thermal properties analyzer operates using a two-pronged probe that is inserted into the medium to be measured; in the case of this study, the moss canopy was measured using the probe. Care was taken to ensure as much of the probe was covered by the moss 
canopy as possible to ensure accurate and consistent results. Each sample was measured using the thermal properties analyzer three times to obtain a mean and account for any small instrument error. The next sample was not drained until the measurements on the prior sample were completed to ensure equal water saturation in each sample. The mass and thermal properties measurements were repeated every day at the same time of day for one week. At the end of one week, all the tubes were transferred to a drying oven at $45^{\circ} \mathrm{C}$ for three days to ensure no water was left in the samples. Another dry mass was taken for each one of the samples so that the water mass at each day of the experiment could be calculated. The water content was quantified in two ways. The first water content measure was the percent water remaining ([water mass/initial water mass]*100). This was simply the percentage of water left each day from total saturation on day one. The next measure was water mass standardized to the core mass ([water mass/total mass of core]*100). This measure accounts for the relative size of the sample core by quantifying exactly how much of the total core mass was contributed by the water content on each day of the experiment. These experimental methods were repeated with the samples collected from Ardley Island.

\section{Laboratory Measures of Canopy Morphology}

To determine differences in moss canopy morphology between the high nitrogen site (Lighthouse) and the low nitrogen site (Ardley Far), gametophyte width and canopy thickness were measured in sample replicates from the previous experiment. These traits were chosen because they had been shown to be phenotypically plastic with nitrogen 
addition (Deakova 2019). In addition, since I hypothesized that water content and thermal properties would be directly linked to canopy density, I also measured the number of gametophytes by canopy area. All three of the measurements were taken from $6 \times 6 \mathrm{~cm}$ replicate moss patches from Ardley Island.

To quantify average gametophyte width, five gametophytes were selected at random from a hydrated moss patch. The gametophytes were selected using a wire grid and a random number generator. A digital caliper was used to measure the width of each gametophyte at its widest point under three conditions. First, the gametophytes were saturated individually by being submerged in spring water in a petri dish for an hour. The petri dish was moved under a dissecting scope and the width was measured. Next, the saturated gametophytes were removed from the water and lightly blotted dry to remove surface water and the width was re-measured. Finally, the gametophytes were allowed to dry completely, and the width was measured once more. It was then determined that the width measurement on the gametophytes that had been hydrated and blotted dry was the most appropriate width measurement to use in analysis as the gametophytes maintained a more hydrated morphology with the leaves in a bloomed structure without being altered by any water cohesion on the surface.

The canopy height measurements were also taken from the $4 \mathrm{~cm} \times 4 \mathrm{~cm}$ replicate moss patches using a digital caliper. Since the $S$. georgicouncinata and C. aciphyllum sample patches did not have soil or rhizoid structures, the height was simply measured from the bottom of the gametophytes to the top of the canopy. The thickness of the sample patches was not perfectly uniform, so the average thickness of five randomly 
selected locations on the patch was used as the average canopy height. The structure of $P$. alpinum has multiple layers of gametophytes mixed with rhizoids in an organic substrate layer. As a result, the canopy height was measured from the bottom of the lowest visible gametophyte in cross section at a specified location to the top of the canopy. Again, these measurement locations were randomly selected five times to get the average canopy height.

Lastly, the $6 \times 6 \mathrm{~cm}$ replicate patches were subsampled to measure the gametophyte density within the canopy. The patches were rehydrated in petri dishes for two hours and were then subsampled using a $13 \mathrm{~mm}$ diameter brass cork borer. In the rare occasion that the canopy was thicker than the length of the borer, a razor blade was used to trim off the excess canopy at the bottom. The subsampled cores were then deconstructed using forceps under a dissecting microscope while counting each individual gametophyte within the canopy.

Statistical Analysis

In the first experiment with five moss species, I used two-way repeated-measures ANOVA to determine the effect of time and species (Polytrichastrum alpinum, Sanionia georgicouncinata, Chorisodontium aciphyllum, Andreaea gainii, and Syntrichia filaris) on the water content and thermal properties of five species. The repeated-measures ANOVA were used because the samples were remeasured daily for seven days to determine the effect of time. The dataset met the assumptions of normality and the 
sphericity was tested using a Mauchly’s Test. A Greenhouse-Geisser sphericity correction was applied to any factors found to be violating the sphericity assumption for the repeated-measures ANOVA. To determine any statistical grouping among species, a post hoc Tukey's honest significant difference (HSD) test was performed on only the final day of the experiment, excluding the factor of time from the post hoc analysis.

The second experiment, with three moss species-across two sites with different nitrogen levels, three-way repeated-measures ANOVA were used to determine the effect of time, species (Polytrichastrum alpinum, Sanionia georgicouncinata, and Chorisodontium aciphyllum) and site (Lighthouse and Ardley Far) on the water content, thermal conductivity, and specific heat capacity. Again, the dataset me the assumptions of normality and a Mauchly's test was used to test for sphericity. Any factors violating the assumptions of sphericity were corrected using a Greenhouse-Geisser sphericity correction. A post hoc test was also performed on the final day of this experiment using a Tukey's HSD test to determine any grouping within species.

Finally, a standard two-way ANOVA was used to determine the effect of site (Lighthouse and Ardley Far) and species (Polytrichastrum alpinum, Sanionia georgicouncinata, and Chorisodontium aciphyllum) on the hydrated gametophyte width, moss canopy thickness, and moss shoot density. This dataset met the assumptions of normality and equal variance for the two-way ANOVA. A post hoc Tukey's HSD test was used once more to determine any statistical grouping within species. All analyses were conducted in $\mathrm{R}$ version 3.6.1 and JMP version 15.2.0. 


\section{RESULTS}

Water Content and Thermal Conductivity across Five Moss Species

The percent water content remaining (water mass/initial water mass) in the sample cores over the course of the experiment was significantly different among species ( $\mathrm{F}=17.326, \mathrm{P}<0.001$, Fig. 3 ) with C. aciphyllum retaining the most water, S. filaris and S. georgicouncinata both retaining a mid-level of water, and P. alpinum and A. gainii retaining significantly less water. Over the seven-day span of the experiment there was a significant downward trend in the percent water remaining within the sample cores for all five experimental species $(\mathrm{F}=14.621, \mathrm{P}<0.001$, Fig. 3). This confirmed the fact that a significant amount of water was being lost from the sample cores of all five species over the experimental time frame. The effect of species across time was not found to be significant $(\mathrm{F}=0.882, \mathrm{P}=0.626)$.

The species difference in the rate of water loss was further emphasized when the water content was standardized to the total mass of the saturated sample core (percent water mass of the total saturated core mass). This standardized core water mass (water mass/total mass of core) decreased significantly over the seven days $(\mathrm{F}=14.621, \mathrm{P}<$ 0.001, Fig. 4), although the ordering of the species differed from that of the percent water remaining (compare Figs. 3 and 4). For this measure, S. georgicouncinata retained the greatest mass of water relative to the total core mass, C. aciphyllum and S. filaris retained a mid-level of water mass, and $A$. gainii and $P$. alpinum retained significantly less water (Fig. 4). The standardized core water mass also decreased significantly over time ( $\mathrm{F}=$ 14.621, P < 0.001, Fig. 4) much like the percent water remaining (compare Figs. 3 and 4). 
Again, the effect of species across time was not found to be significant $(\mathrm{F}=0.696, \mathrm{P}=$ $0.850)$.

Across the five species there was a significant difference in thermal conductivity $(\mathrm{W} /[\mathrm{m} * \mathrm{~K}])(\mathrm{F}=41.506, \mathrm{P}<0.001$, Fig. 5) with grouping that mirrored those visible in the standardized core water mass (compare Figs. 4 and 5). C. aciphyllum consistently showed the highest thermal conductivity with very little drop off over time despite the significant drop in water content. S. filaris and S. georgicouncinata both showed a midlevel thermal conductivity with a greater drop off over time than $C$. aciphyllum, while $P$. alpinum and A. gainii both had a significantly lower thermal conductivity (Fig. 5). Specific heat capacity $(\mathrm{J} /[\mathrm{kg} * \mathrm{~K}])$ was also significant across species $(\mathrm{F}=48.576, \mathrm{P}<$ 0.001, Fig. 6) with a very similar species grouping as was seen in thermal conductivity. Both thermal conductivity $(\mathrm{F}=19.345, \mathrm{P}<0.001$, Fig. 5$)$ and specific heat capacity $(\mathrm{F}=$ 18.691, P < 0.001, Fig. 6) were shown to decrease significantly over the experimental time frame across the combined species. However, the effect of species across time was not found to be significant in either thermal conductivity $(F=0.560, P=0.951)$ or specific heat capacity $(\mathrm{F}=0.531, \mathrm{P}=0.964)$.

\section{Qualifying Tissue Nitrogen Content}

Following combustion analysis of moss tissue from all three species across the four initial Ardley sites, it was found that samples from the Lighthouse site were the only samples with a tissue nitrogen content that was statistically unique $(\mathrm{F}=12.186, \mathrm{P}<$ 
0.001, Fig. 7). Since the remaining three sites were statistically similar in tissue nitrogen content, Lighthouse (LH) was chosen as the "high nitrogen" site, and the site furthest away, Ardley Far (AF), was chosen as the "low nitrogen" site. The remaining intermediate sites were eliminated from the analysis.

\section{Water Content and Thermal Conductivity across Two Sites and Three Moss Species}

The percent water mass remaining in the sample cores over the course of the experiment was shown to be significantly greater in the low nitrogen site than in the high nitrogen site $(F=14.752, P<0.001$, Fig. 8). The effect of species here was again shown to be significant $(\mathrm{F}=13.798, \mathrm{P}<0.001)$ as was the effect of time $(\mathrm{F}=99.990, \mathrm{P}<0.001$, Fig. 8) mirroring results from the five species experiment prior. In addition, the effect of site by species on percent water mass remaining was significant $(\mathrm{F}=7.955, \mathrm{P}<0.001)$ indicating that the magnitude of the effect of site was significantly different between species with C. aciphyllum showing the greatest difference between sites. The effects of time by site $(\mathrm{F}=1.118, \mathrm{P}=0.354)$, time by species $(\mathrm{F}=0.676, \mathrm{P}=0.773)$, and time by site by species $(\mathrm{F}=0.325, \mathrm{P}=0.984)$ were not found to be significant.

Like with the percent water mass remaining, the standardized core water mass was significantly different between sites $(\mathrm{F}=78.669, \mathrm{P}<0.001$, Fig. 9) but showed the opposite results (compare Figs. 8 and 9); the percent water mass was significantly greater in the high nitrogen site than in the low nitrogen site. The effect of species was also found to be significant $(F=223.104, P<0.001)$ as was the effect of time $(F=10.489, P$ 
$<0.001$, Fig. 9) again mirroring the results of the five species experiment prior. Similar to the percent water remaining, the effect of site by species was found to be significant for the standardized core water mass $(\mathrm{F}=13.739, \mathrm{P}<0.001)$ with $P$. alpinum this time showing the greatest difference between sites. Again, the effects of time by site $(\mathrm{F}=$ $0.004, \mathrm{P}=1.00)$, time by species $(\mathrm{F}=0.571, \mathrm{P}=0.863)$, and time by site by species $(\mathrm{F}=$ $0.112, \mathrm{P}=1.00)$ were not found to be significant.

When the thermal traits were compared between the two sites, the low nitrogen site had a significantly greater thermal conductivity $(F=56.053, P<0.001$, Fig. 10) and specific heat capacity $(\mathrm{F}=45.578, \mathrm{P}<0.001$, Fig. 11$)$. The effect of species was shown to be significant for both thermal conductivity $(\mathrm{F}=59.540, \mathrm{P}<0.001)$ and specific heat capacity $(\mathrm{F}=59.564, \mathrm{P}<0.001)$ with $C$. aciphyllum showing both the greatest thermal conductivity and specific heat capacity. Finally, the effect of time for both thermal conductivity $(\mathrm{F}=21.674, \mathrm{P}<0.001$, Fig. 10$)$ and specific heat capacity $(\mathrm{F}=14.833, \mathrm{P}<$ 0.001, Fig. 11) proved to be significant with both values decreasing over time. Time by site $(F=1.185, P=0.317)$, time by species $(F=0.386, P=0.967)$, site by species $(F=$ $0.957, \mathrm{P}=0.386)$, and time by site by species $(\mathrm{F}=0.274, \mathrm{P}=0.992)$ were not shown to be significant for thermal conductivity, nor were time by site $(F=0.905, P=0.493)$, time by species $(\mathrm{F}=0.282, \mathrm{P}=0.991)$, site by species $(\mathrm{F}=1.917, \mathrm{P}=0.150)$, and time by site by species $(F=0.273, P=0.993)$ found to be significant for specific heat capacity. 


\section{Moss Canopy Morphology across Two Sites and Three Species}

Elevated nitrogen content within the tissue of the three experimental species was shown to have a significant impact on all three measured morphological canopy traits. The hydrated gametophyte width (blotted width) in the high nitrogen site was shown to be significantly greater than in the low nitrogen site $(F=30.822$, $P<0.001$, Fig. 12$)$ for all three species. There was also a strong species difference in all three measured morphological traits. P. alpinum consistently exhibited the greatest hydrated gametophyte width in both sites and S. georgicouncinata exhibited the smallest hydrated gametophyte width $(\mathrm{F}=96.886, \mathrm{P}<0.001$, Fig. 12). In addition, the magnitude of the difference in hydrated gametophyte width between sites was significantly greater in $P$. alpinum than in the other two species $(\mathrm{F}=4.989, \mathrm{P}=0.017)$.

The patch thickness was shown to be significantly greater in the high nitrogen site as well $(\mathrm{F}=10.316, \mathrm{P}=0.004$, Fig. 13$)$ with $C$. aciphyllum showing the greatest individual species increase in patch thickness $(\mathrm{F}=5.955, \mathrm{P}=0.009$, Fig. 13). Both $P$. alpinum and S. georgicouncinata showed increased patch thickness in the high nitrogen site but in a lesser magnitude than that of $C$. aciphyllum. The patch thickness was significantly different across species with $C$. aciphyllum showing the greatest patch thickness, especially in the high nitrogen site, and S. georgicouncinata showing the smallest patch thickness in both sites $(\mathrm{F}=18.948, \mathrm{P}<0.001$, Fig. 13).

Finally, all three species showed an increased gametophyte density in the high nitrogen site $(\mathrm{F}=14.982, \mathrm{P}<0.001$, Fig. 14) although the effect of site by species was not shown to be significant $(\mathrm{F}=2.574, \mathrm{P}=0.101)$. The gametophyte density was 
significant among species $(\mathrm{F}=80.247, \mathrm{P}<0.001$, Fig. 14) with $C$. aciphyllum having the greatest shoot density in both sites while $P$. alpinum had the lowest shoot density in both sites. 


\section{DISCUSSION}

In this study, using moss cores sampled from King George Island (KGI) on the Western Antarctic Peninsula, I measured the relative water content in the moss canopy using mass, as well as the thermal conductivity and specific heat capacity to understand the insulation ability of the mosses. I found that not only do different species of Antarctic mosses have significantly different thermal conductivities, but they also fall into functional groups with respect to their thermal conductivities. Chorisodontium aciphyllum consistently had the greatest thermal conductivity and water retention, Sanionia georgicouncinata and Syntrichia filaris both showed a mid-level thermal conductivity, and Andreaea gainii and Polytrichastrum alpinum both had significantly lower thermal conductivities (Fig. 5). In addition, I found that mosses with an elevated tissue nitrogen had a greater canopy density (Figs. 12, 13, and 14) and relative water mass (Fig. 9) but had lesser thermal conductivity (Fig. 10) and specific heat capacity (Fig. 11).

Thermal conductivity is a measure of the ability of a material to transfer or conduct heat from one side of the material to the other, while specific heat capacity shows how much energy is required to change the temperature of a material directly (Ruuska et al. 2017). These measurements, which are very common is assessing building insulation, were also the most applicable for assessing thermal applications of moss canopies in this study. For instance, a moss mat with a lower thermal conductivity would be less efficient at transferring ambient temperature to the substrate below. Studies have shown moss to be involved in temperature regulation in a variety of different systems. In 
the United Kingdom, songbird nests with a higher proportion of moss and feathers incorporated into the nest structure had a strong positive correlation with insulatory values (Deeming et al. 2020). In an experimental moss removal study in a Siberian tundra ecosystem, both ground heat flux and evapotranspiration were shown to increase in sites where moss had been removed suggesting a strong insulating effect (Blok et al. 2011). Since water is an excellent conductor of heat, I hypothesized that greater water retention would lead to greater thermal conductivity and, therefore, a reduced ability to insulate the substrate. First, these factors were measured across five species, a "feather moss" Sanionia georgicouncinata, a "turf moss," Polytrichastrum alpinum, and three other mosses common near the study site, Chorisodontium aciphyllum, Andreaea gainii, and Syntrichia filaris. This was done largely to assess differences in water holding capacity and insulation ability among species of varying functional groups. It was evident in this study that there were significant differences among moss species both in their ability to hold water within their canopies (Figs. 3 and 4) and in their ability to insulate heat (Figs. 5 and 6). This indicates that it is not enough to simply assume that mosses will play a role in permafrost preservation without also discussing the species composition of the site in question. With this knowledge, determining which moss species will be the dominant ground cover in the region would give insight into the temperature dynamics and permafrost vulnerability in the future. Below I discuss these data in more detail and the potential role of nutrient limitation in influencing moss thermal properties. 


\section{Water Content and Thermal Conductivity}

Both the thermal conductivity and the specific heat capacity were shown to be significantly different across species with $C$. aciphyllum showing the greatest values for both measures, and the remaining species arranging into clear functional groups (Figs. 5 and 6). This largely mirrors the results for the water content measures. Considering $C$. aciphyllum has the greatest and most densely packed biomass in the canopy limiting free airflow, I hypothesized that it would also be the most efficient at retaining water, which then would lead to a high thermal conductivity due to the high thermal conductivity of water; this dynamic has been observed in mosses in more temperate urban environments (Rice et al. 2018). However, this result was dependent upon how the water content was standardized. When the water content was standardized by the initial water mass (percent water mass remaining), C. aciphyllum indeed retained the greatest water mass (Fig. 3), but when the water content was standardized by the total saturated core mass including biomass (relative water mass of the sample core), S. georgicouncinata showed the greatest relative water content (Fig. 3). This is most likely due to the canopy structure of the two mosses. C. aciphyllum, as previously stated, has a tall, dense canopy almost entirely made up of senescent tissue. This makes for an excellent medium for water absorption; however, the large amount of biomass contributing to the overall core mass meant that the relative water content was lower. S. georgicouncinata, on the other hand, is also very efficient at absorbing water in the canopy due to the high surface area and tangled structure of the canopy but has comparatively low biomass and little senescent tissue in the canopy leading to a greater overall relative water content. C. aciphyllum was 
also found to have both the greatest thermal conductivity and specific heat capacity (Figs. 5 and 6) reinforcing my hypothesis that a greater water retention leads to a higher conductivity. Water also has a high specific heat capacity which is likely the cause of the high specific heat capacity in the C. aciphyllum. The species grouping shown by Tukey's HSD test reinforces the concept of morphological functional groups influencing how individual species interact with their environment. For thermal conductivity, specific heat capacity, and both standardizations of water content, $P$. alpinum and A. gainii were grouped together while S. georgicouncinata and S. filaris grouped together. P. alpinum and A. gainii both fit the definition of a "turf moss" specifically in their upright gametophyte structure, abundance of empty space within their canopies, and their tendency to collect sediment (Putzke and Pereira 2001). S. georgicouncinata and S. filaris have similar morphologies to each other and fit the definition of a "feather moss" with a shorter stature, less empty space in the canopy and "frond like" gametophytes (Putzke and Pereira 2001). This suggests, unsurprisingly, that the morphology of the moss plays a strong role in the moss' water holding capacity and ability to insulate, further emphasizing the importance of considering species composition when assessing moss communities in an ecosystem.

Plant functional groups are used widely to understand the role of species in the community (Thomas et al. 2019). Vascular plants are often organized into functional groups based on a variety of ecological factors, from plant life cycle (annual versus perennial) and plant growth structure (graminoid versus forb) (Freund et al. 2021), to nitrogen fixation (Davison et al. 2020). However, few studies have used functional traits 
to apply this organization to moss species, instead lumping most moss species together with the majority of species specific moss research being done on Sphagnum species (Ehrenfeld et al. 2005, O’Donnell et al. 2009). Studies that organize bryophyte functional groups have largely focused on traits such as soil retention or nitrogen cycling and are often extremely broad (Smith et al. 2015). These functional groups are useful for drawing conclusions regarding roles that mosses might fill in an ecosystem beyond simply their growth structure or nutrient feedbacks. Here, I show that bryophytes also fall into functional groups with respect to their thermal properties as well. Understanding the effect of mosses on the temperature dynamics of an ecosystem is valuable not only in environments with a vulnerable permafrost layer, but also more broadly due to the multitude of ecosystem functions that are temperature dependent, such as invertebrate communities (Robinson et al. 2021) or temperature dependent seed germination (Roberts 1988). This study shows how mosses can be categorized not just by their morphologies and nutrient functions, but also by their thermal properties and their water holding capacity.

Nitrogen Availability

The effect of elevated tissue nitrogen was shown to be significant for the thermal properties as well as both the percent water mass remaining in the canopy over time and the relative water mass in the moss core. However, the direction of the effect was conflicting between the two water content standardizations. On the final day of the experiment, the mosses from the low nitrogen site had a significantly greater percentage 
of the initial saturated water mass remaining in the canopy (Fig. 8) but had a lower overall relative amount of water in the canopy than the mosses from the high nitrogen site (Fig. 9). This indicates that while the low nitrogen mosses retained more water than the high nitrogen mosses, they held less water mass overall. Additionally, the thermal conductivity and specific heat capacity were both significantly affected by elevated tissue nitrogen with both values being higher in the low nitrogen mosses (Figs. 10 and 11). This means that despite the increased amount of water in the high nitrogen mosses, the low nitrogen mosses still conducted heat more efficiently suggesting that while the water content plays an important role in the insulation abilities of moss canopies, the canopy morphology and where the water is held within the canopy also have a large impact on the insulation ability.

Nutrient loading, specifically with elevated nitrogen levels, can have a significant effect on plant morphology, which has been demonstrated in a wide variety of climates and ecosystems (Brunner and Brodbeck 2001, Quesada et al. 2012, van der Sande et al. 2018, Hofhansl et al. 2021). Acer mono seedlings treated with nitrogen fertilizer exhibited greater plant height and root diameter in the cold monsoon climate of Heilongjiang, China (Razaq et al. 2017), and a variety of Mediterranean Quercus species showed increased dry biomass due to nitrogen fertilization (Sanz Pérez et al. 2007). These effects have been observed in mosses as well with higher fresh weights and dry weights being measured in shade grown Sphagnum capillifolium treated with nitrate fertilizer (Manninen et al. 2011). Physiological and biochemical responses to elevated nutrients could potentially be used to identify communities that will be better equipped to 
adapt to the changing environment due to global warming (Wasley et al. 2006). In this study, all measured species ( $S$. georgicouncinata, $P$. alpinum, and $C$. aciphyllum) showed increased hydrated gametophyte width, canopy thickness, and shoot density in the high nitrogen site (Figs. 12, 13, and 14), indicating a denser canopy structure and greater overall biomass with elevated tissue nitrogen. This clearly shows that not only is the tissue nitrogen concentration able to significantly affect the canopy morphology, but the magnitude of the effect is enough to reflect in the water content and the thermal properties.

I can propose several possibilities for why the mosses from the high nitrogen site had a lower thermal conductivity and specific heat capacity than the mosses from the low nitrogen site despite clearly having a denser canopy and greater relative water mass. The differences in the canopy structure could potentially alter where the water is stored within the sample core. The greater biomass in the high nitrogen mosses could potentially be displacing the water, shifting it to the bottom of the core rather than being more evenly dispersed within the upper canopy. This would mean that despite the increased water mass, the heat is required to travel through more plant tissue to disperse, decreasing the overall thermal conductivity. In addition, water can be held either within moss tissue or in the moss canopy, and in our study species it is unknown what proportion of water is held in these two locations, as the mosses dry. Water in these two locations are likely to vary in how they affect evapotranspiration versus their impact on the canopy morphology and insulation ability of the moss. Further experimentation in determining the intracellular water content as compared to the external water content held within the 
canopy would certainly help to clarify these effects. Also, since mosses such as $C$.

aciphyllum and S. georgicouncinata can retain substantial water, they may potentially alter the water content of the substrate below. If the majority of the available water is being stored within the moss canopy, the mosses could likely be causing a drying affect in the below ground system, essentially preventing moisture from reaching the soil layer. If more water is being held closer to the surface of the substrate rather than draining deeper, there would likely be significantly greater evapotranspiration within the canopy contributing to an overall drying affect. These changes in water content of both above ground moss canopies as well as the below ground system could have implications for fungal and micro-invertebrate communities in the system. Moss dwelling microinvertebrates are often sensitive to changes in temperature and moisture content in their habitat. Their abundance and species richness has been shown to be positively correlated with nitrogen concentrations of mosses and other cryptogams in Antarctica (Bokhorst et al. 2019). The changes in water content and insulation ability in mosses due to elevated nitrogen could potentially be a significant factor in this relationship between invertebrate abundance and nitrogen concentration.

Further analysis is needed regarding where water is stored within the moss canopy in this system to determine the details of moss canopy water dynamics and how changes in the canopy morphology would affect these dynamics. Additionally, measuring chlorophyll content and chlorophyll florescence in both high and low nitrogen sites would lend insight into changes in photosynthetic activity as well as relative stress levels in the mosses that could affect water uptake and storage as well as canopy structure (Liu 
et al. 2016, Ding et al. 2018, Evans and Clarke 2019). To further separate moss functional groups in terms of their insulation ability, a more materials-physics based approach may be beneficial. An estimation of an $\mathrm{R}$ value range by species (defined by the temperature difference between the "hot side" and "cold side" of a material divided by the heat flux through the barrier) would be useful for this classification as it would be a single value or range that can be contrasted with other species and incorporated into functional grouping strategies. R-values are also often used in building construction because of their clear and concise representation of heat resistance making them relevant values that can be applied to a wide variety of materials (Gentle et al. 2011, Corscadden et al. 2014, Bakatovich and Gaspar 2019). Lastly, a consideration of moss pigmentation and albedo would be relevant in addition to the thermal properties in determining moss functional groups. Moss albedo would impact the temperature dynamics of an ecosystem by reflecting solar radiation away from the substrate rather than simply insulating the substrate from existing heat (Bowler et al. 2010, Porada et al. 2016, Xiao and Bowker 2020, Yue et al. 2020). The albedo and thermal properties together would present a more complete concept of how mosses are able to influence the temperature dynamics of their ecosystem.

\section{Conclusion}

As the maritime Antarctic ecosystem continues to warm, glacial retreat and increased annual snow melt will further expose subterranean permafrost to warmer conditions (Amesbury et al. 2017). One of the most visible changes in the ecosystem is 
the colonization of the new ice-free areas by bryophytes, more specifically mosses (Knelman et al. 2012, Castle et al. 2016). To make educated predictions regarding the future of this ecosystem including the permafrost, there needs to be a better understanding of the role bryophytes fill with regards to thermal regulation in this unique system and how abiotic factors, such as elevated soil nitrogen, might affect that role. To build a better understanding of these roles in maritime Antarctica, thermal properties and water dynamics were measured in several species of Antarctic moss representing different functional and morphological groups (Smith et al. 2015) on King George Island. In addition, since increased decomposition and other biotic factors, such as migrating penguin colonies, can produce localized spikes in soil nitrogen concentrations (Park et al. 2007, Bokhorst et al. 2019, Wang et al. 2020), the effect of elevated nitrogen on morphology, water dynamics, and thermal properties was measured.

I found that the effect of species was significant for both the thermal properties and the water content organizing the study species into functional groups. The "turf mosses," with greater empty space within their canopies, had the lowest thermal conductivity while the "feather mosses," with less empty space in the canopy and a flatter more tangled morphology had significantly greater thermal conductivity. However, none of these species had a thermal conductivity as high as Chorisodontium aciphyllum with its tall, dense canopy. These data reflected water retention results across species suggesting a correlation between the water retention in the moss canopy and the insulation ability of the moss. In addition, the functional grouping of the mosses based on their thermal properties shows that the effect of moss colonization on permafrost 
vulnerability in glacial ecosystems is species dependent. Further research into physiological and ecological factors that contribute to functional grouping of bryophytes is pertinent.

I also found the elevated tissue nitrogen significantly affected canopy thickness and density which in turn affected the thermal properties and water content of the moss canopies. The mosses with higher tissue nitrogen showed increased canopy density and water content, but also showed a lower thermal conductivity and specific heat capacity. This indicates that as warming continues and nitrogen becomes more available in the ecosystem due to increased decomposition and penguin migration (Lee et al. 2009), the roles these mosses fill with respect to their temperature regulation and water retention will change as well. However, further analyses are required to better understand the specific mechanism in which canopy morphology, water content, and thermal conductivity are related in this system. The results of this study could be improved by analyzing the thermal properties of moss species using methods common in materials engineering, such as approximating an insulation R-value. This value, more common in building insulation materials, is an efficient single value that measures how effectively a material resists heat flow under steady state conditions (Kośny and Yarbrough 2017). Assigning an R-value or range of R-values to moss species in the community would help contribute to more clear parameters for functional classification. In addition, the inclusion of moss pigmentation and albedo measurements would supplement the thermal properties by presenting a more complete picture of how mosses influence the temperature dynamics of their ecosystem. The thermal properties of mosses as well as 
species differences in their ecosystem functions are often overlooked. In an ecosystem as rapidly warming as King George Island, considering the changing temperature dynamics of the system is more important than ever. As the primary colonizers of maritime Antarctica, understanding role of mosses in the ecosystem is critical to anticipating how the ecosystem structure will continue to shift under global warming. 


\section{FIGURES}



Figure 1. Fildes Peninsula on King George Island (KGI). Location of Julio Escudero

Research Base and sampling location for Polytrichastrum alpinum, Sanionia

georgicouncinata, Chorisodontium aciphyllum, Andreaea gainii, and Syntrichia filaris. 


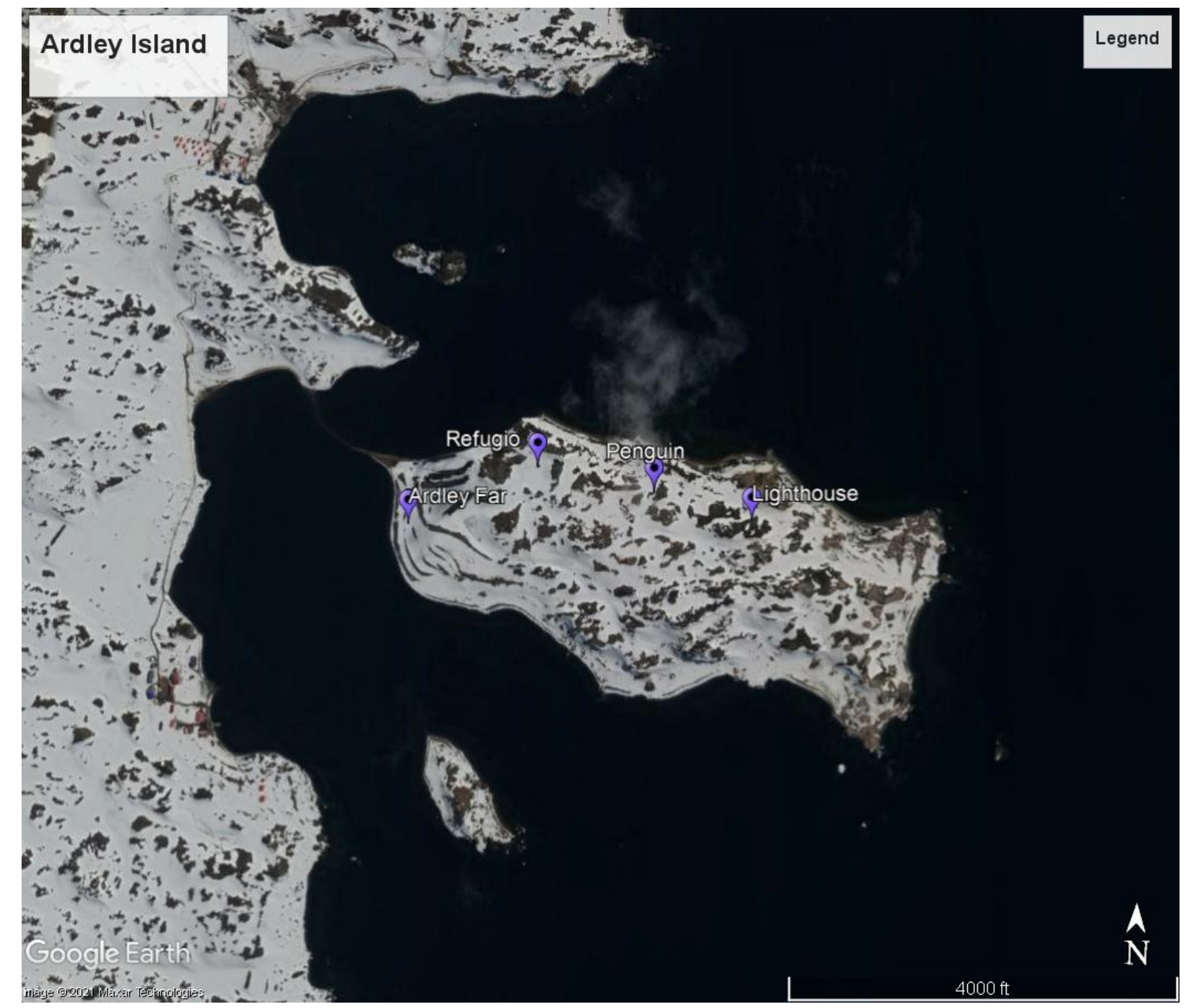

Figure 2. Ardley Island of eastern coast of King George Island. Pins represent sampling locations of Polytrichastrum alpinum, Sanionia georgicouncinata, and Chorisodontium aciphyllum. A gentoo penguin colony is in proximity to the Lighthouse (LH) site and represents the epicenter of the soil nitrogen spike. 


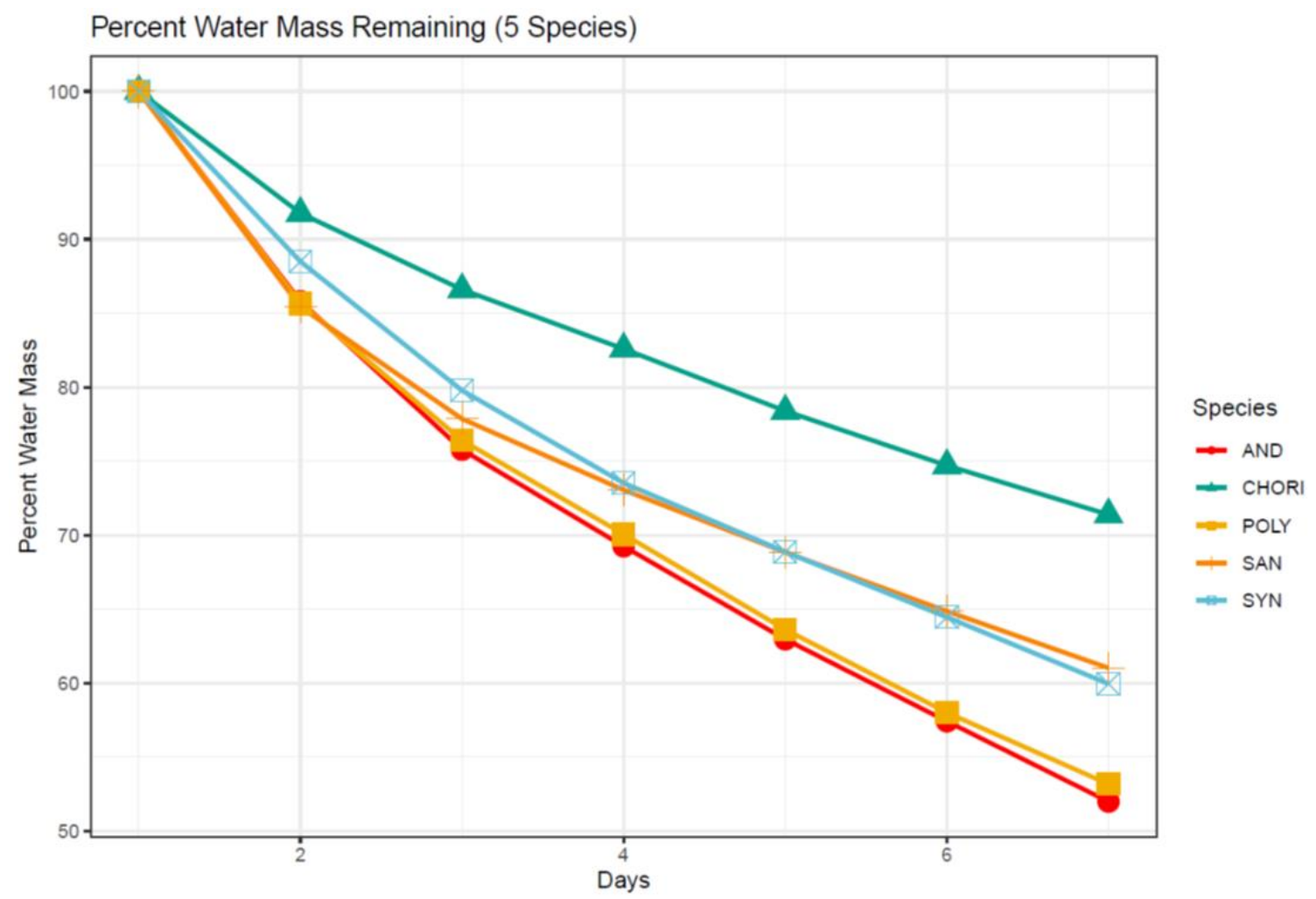

Figure 3. The percent water mass remaining in the canopy of the moss sample core over seven days differs significantly among the five species $(\mathrm{F}=17.326, \mathrm{P}<0.001)$. All samples began at full saturation on day one (100\% water mass) and percentages for days 2-7 were relative to full saturation. $\mathrm{AND}=$ Andreaea gainii, $\mathrm{CHORI}=$ Chorisodontium aciphyllum, $\mathrm{POLY}=$ Polytrichastrum alpinum, $\mathrm{SAN}=$ Sanionia georgicouncinata, and SYN = Syntrichia filaris. All samples were collected from the same site on the Fildes Peninsula $\left(62.201382^{\circ} \mathrm{S}, 58.962358^{\circ} \mathrm{W}\right)$. 


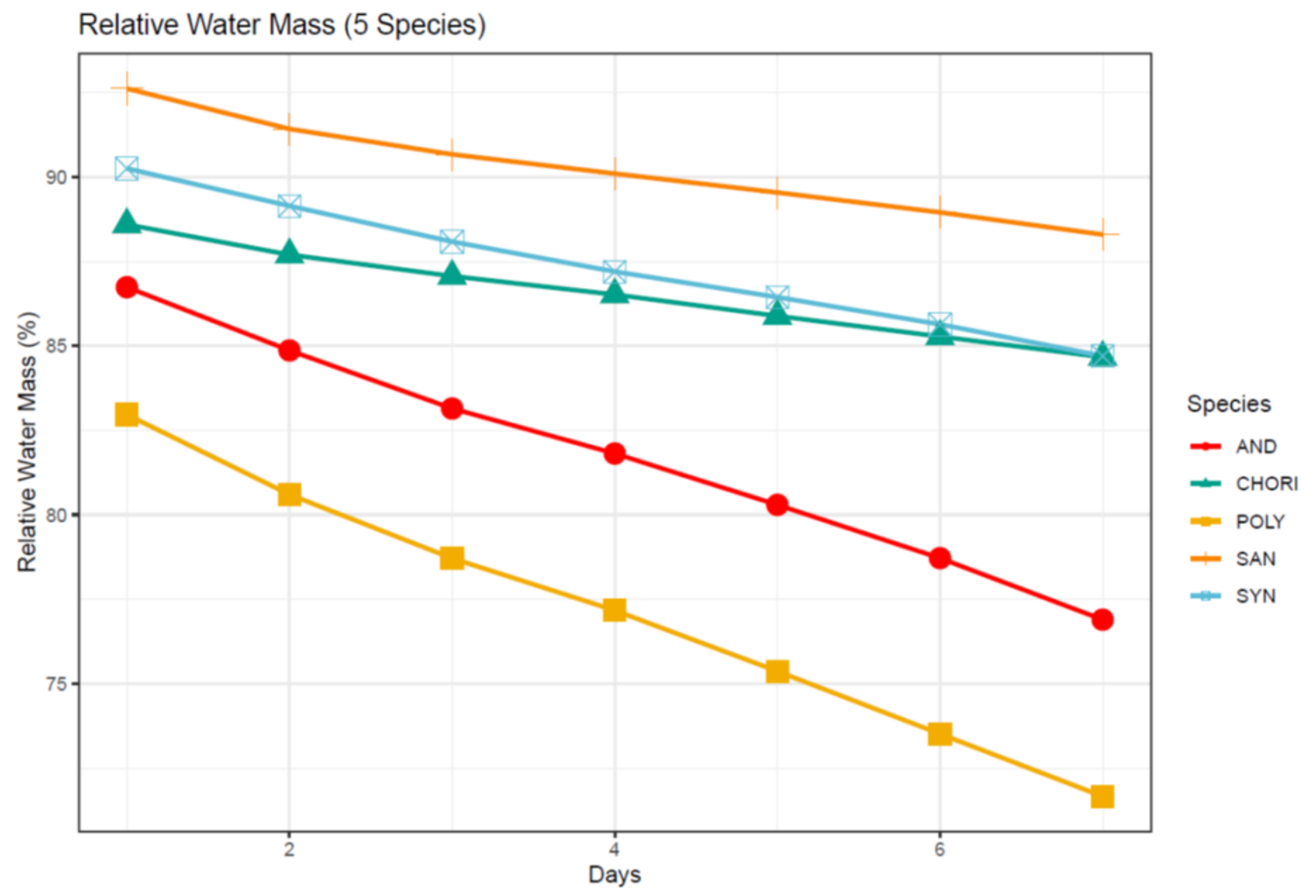

Figure 4. Percentage of the total moss sample core mass that is contributed by the water content for five species. The species were found to be significantly different $(\mathrm{F}=91.155$, $\mathrm{P}<0.001) . \mathrm{AND}=$ Andreaea gainii, $\mathrm{CHORI}=$ Chorisodontium aciphyllum, $\mathrm{POLY}=$ Polytrichastrum alpinum, SAN = Sanionia georgicouncinata, and SYN = Syntrichia filaris. All samples were collected from the same site on the Fildes Peninsula $\left(62.201382^{\circ} \mathrm{S}, 58.962358^{\circ} \mathrm{W}\right)$. 


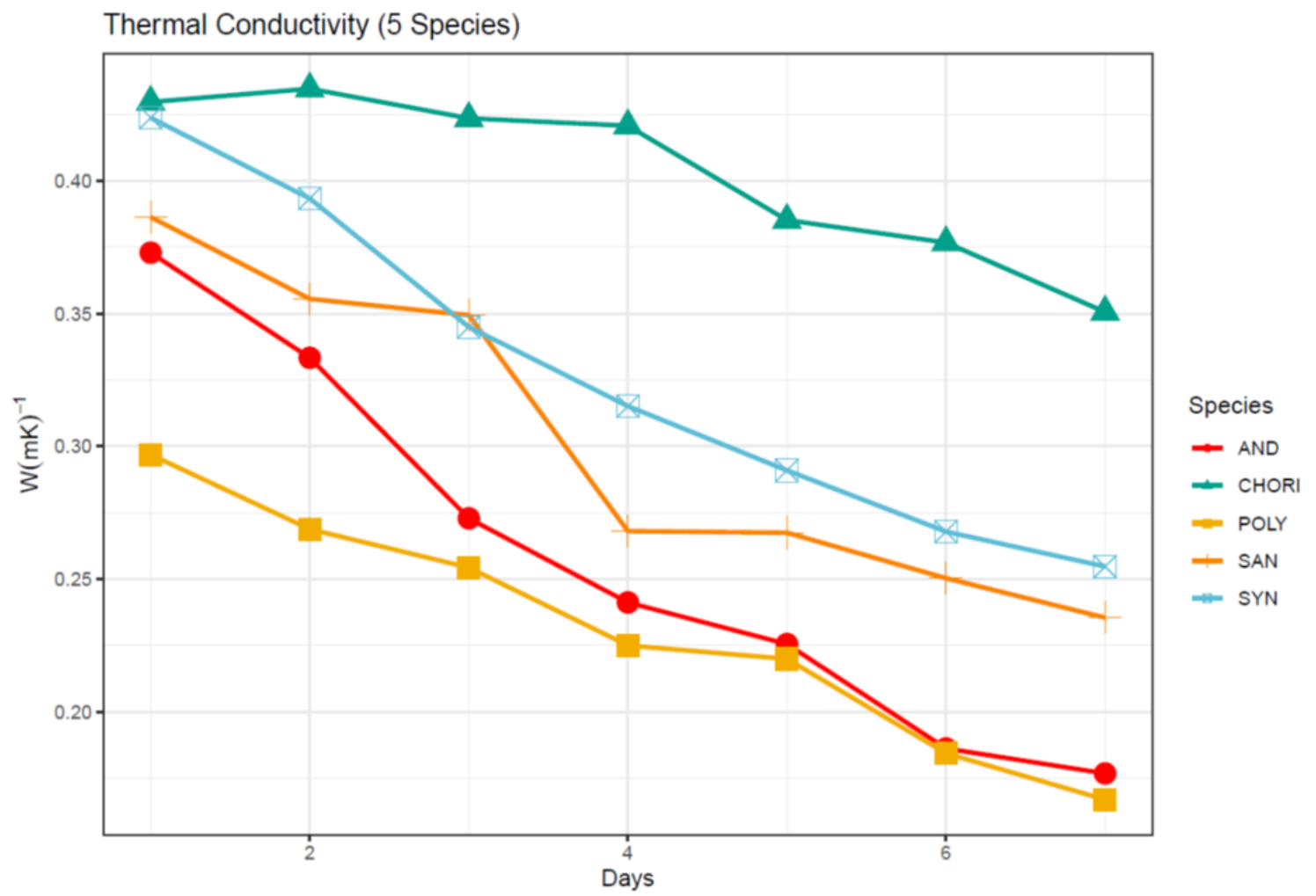

Figure 5. Thermal conductivity $\left(\mathrm{W}\left(\mathrm{m}^{*} \mathrm{~K}\right)^{-1}\right)$ for five species over seven days. Species were found to be significantly different $(\mathrm{F}=19.345, \mathrm{P}<0.001)$. AND $=$ Andreaea gainii , $\mathrm{CHORI}=$ Chorisodontium aciphyllum, $\mathrm{POLY}=$ Polytrichastrum alpinum, $\mathrm{SAN}=$ Sanionia georgicouncinata, and SYN = Syntrichia filaris. All samples were collected from the same site on the Fildes Peninsula $\left(62.201382^{\circ} \mathrm{S}, 58.962358^{\circ} \mathrm{W}\right)$. 


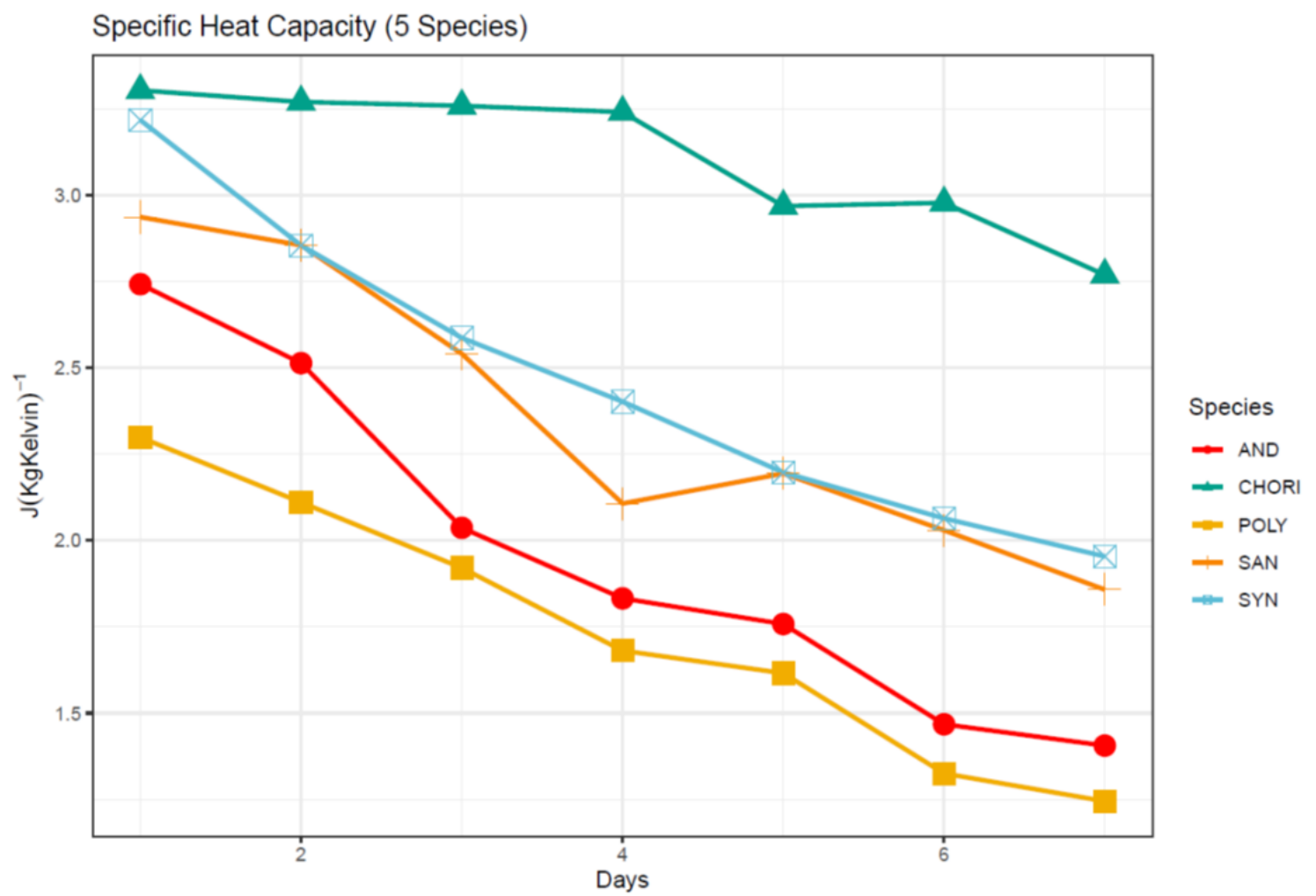

Figure 6. Specific heat capacity $\left(\mathrm{J}\left(\mathrm{Kg}^{*} \mathrm{~K}\right)^{-1}\right)$ for five species over seven days. Species were found to be significantly different $(\mathrm{F}=18.691, \mathrm{P}<0.001)$. AND $=$ Andreaea gainii , $\mathrm{CHORI}=$ Chorisodontium aciphyllum, $\mathrm{POLY}=$ Polytrichastrum alpinum, $\mathrm{SAN}=$ Sanionia georgicouncinata, and SYN = Syntrichia filaris. All samples were collected from the same site on the Fildes Peninsula $\left(62.201382^{\circ} \mathrm{S}, 58.962358^{\circ} \mathrm{W}\right)$. 


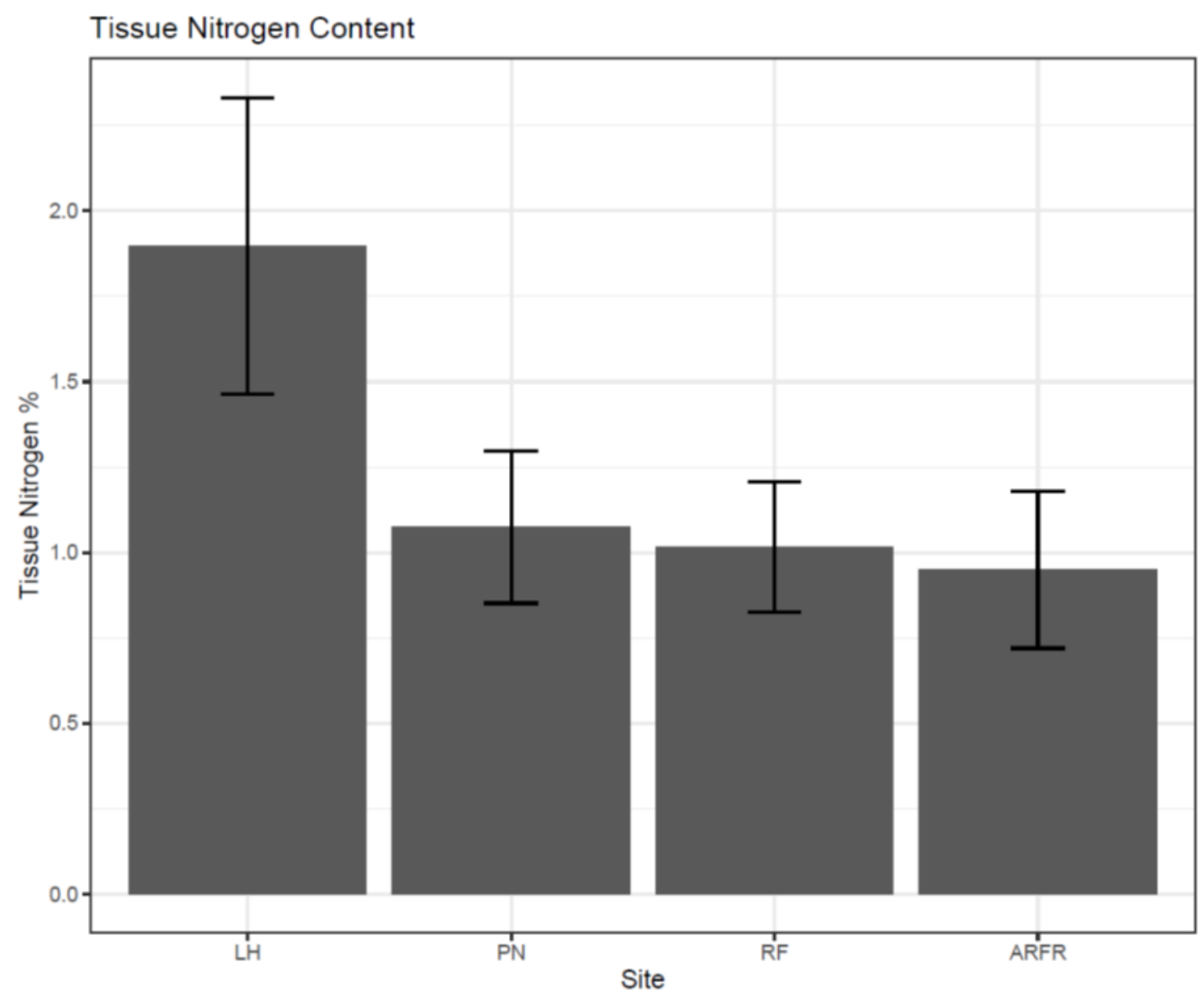

Figure 7. Tissue nitrogen content measured through combustion analysis by the Cornell Nutrient Analysis Lab. Lighthouse (LH) site was statistically different from the other three sites $(\mathrm{F}=12.186, \mathrm{P}<0.001)$. Five samples from Polytrichastrum alpinum, Sanionia georgicouncinata, and Chorisodontium aciphyllum from each site were included in the analysis. 


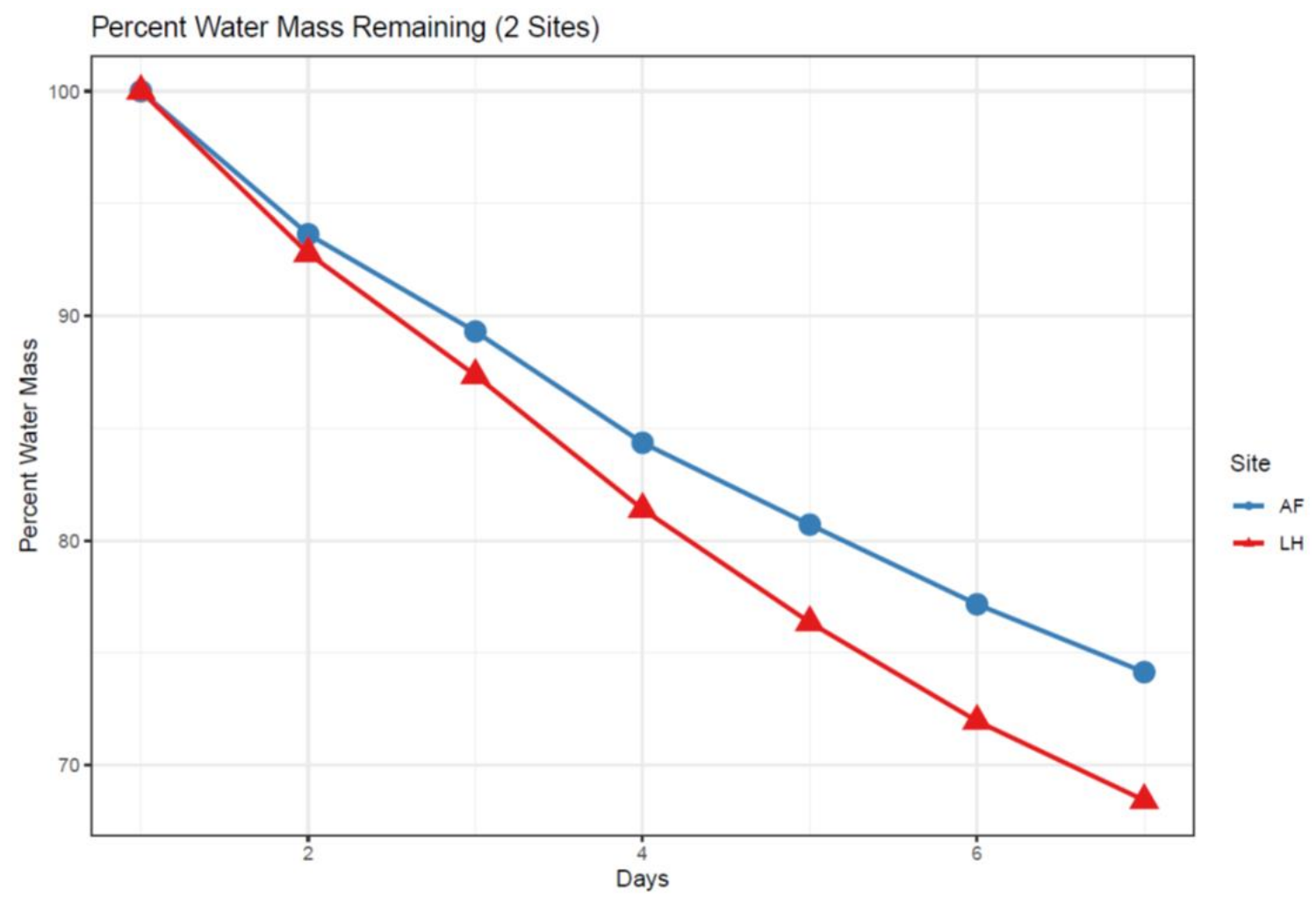

Figure 8 . The percent water mass remaining in the canopy of the moss sample core over seven days for two sites on Ardley Island. Sites were found to be significantly different $(\mathrm{F}=14.752, \mathrm{P}<0.001)$. LH (Lighthouse) represents high tissue nitrogen and AF (Ardley Far) represents low tissue nitrogen. All samples began at full saturation on day one (100\% water mass) and percentages for days 2-7 were relative to full saturation. Polytrichastrum alpinum, Sanionia georgicouncinata, and Chorisodontium aciphyllum were included in each site. 


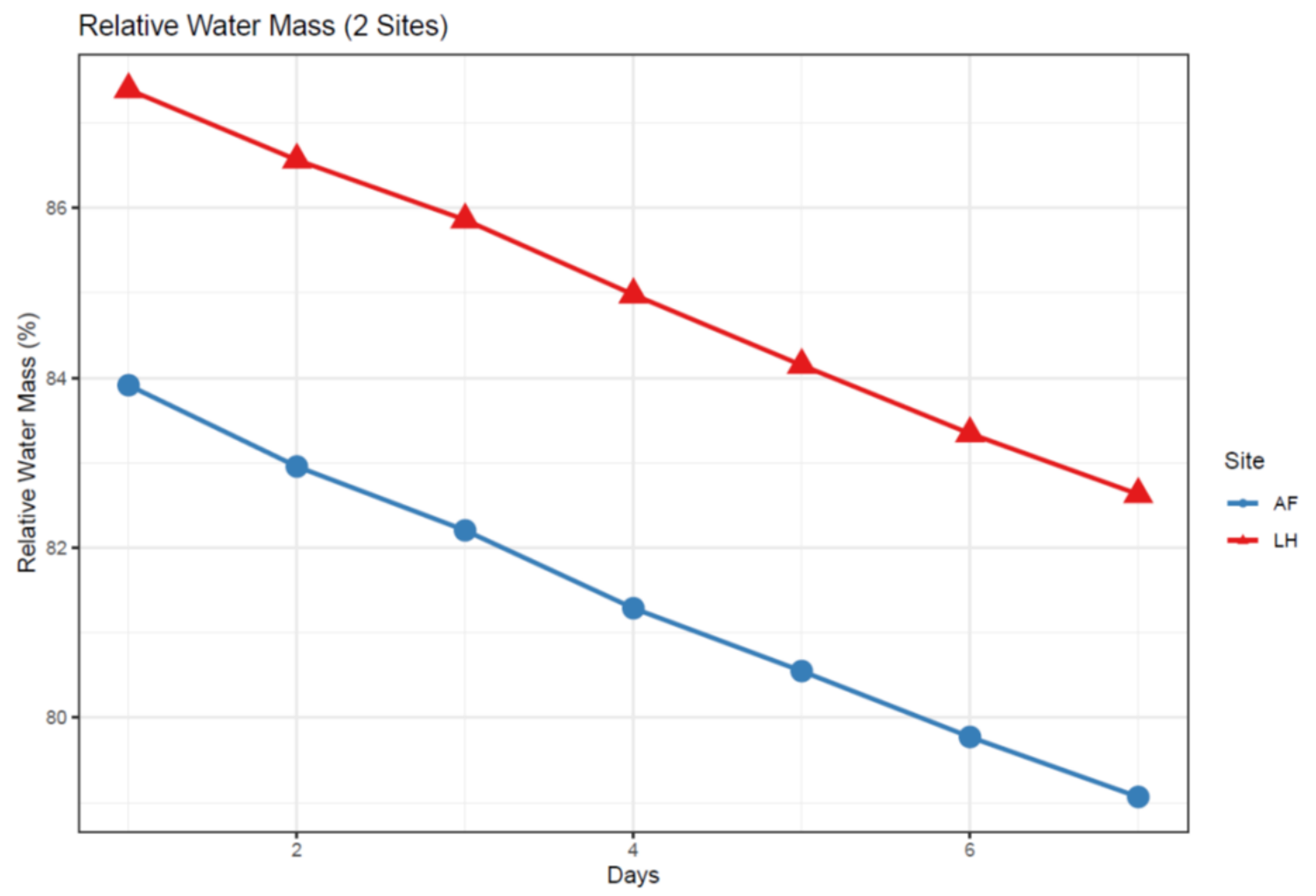

Figure 9. Percentage of the total moss sample core mass that is contributed by the water content for two sites on Ardley Island. Sites were found to be significantly different (F = 78.669, $\mathrm{P}<0.001)$. LH (Lighthouse) represents high tissue nitrogen and AF (Ardley Far) represents low tissue nitrogen. Polytrichastrum alpinum, Sanionia georgicouncinata, and Chorisodontium aciphyllum were included in each site. 


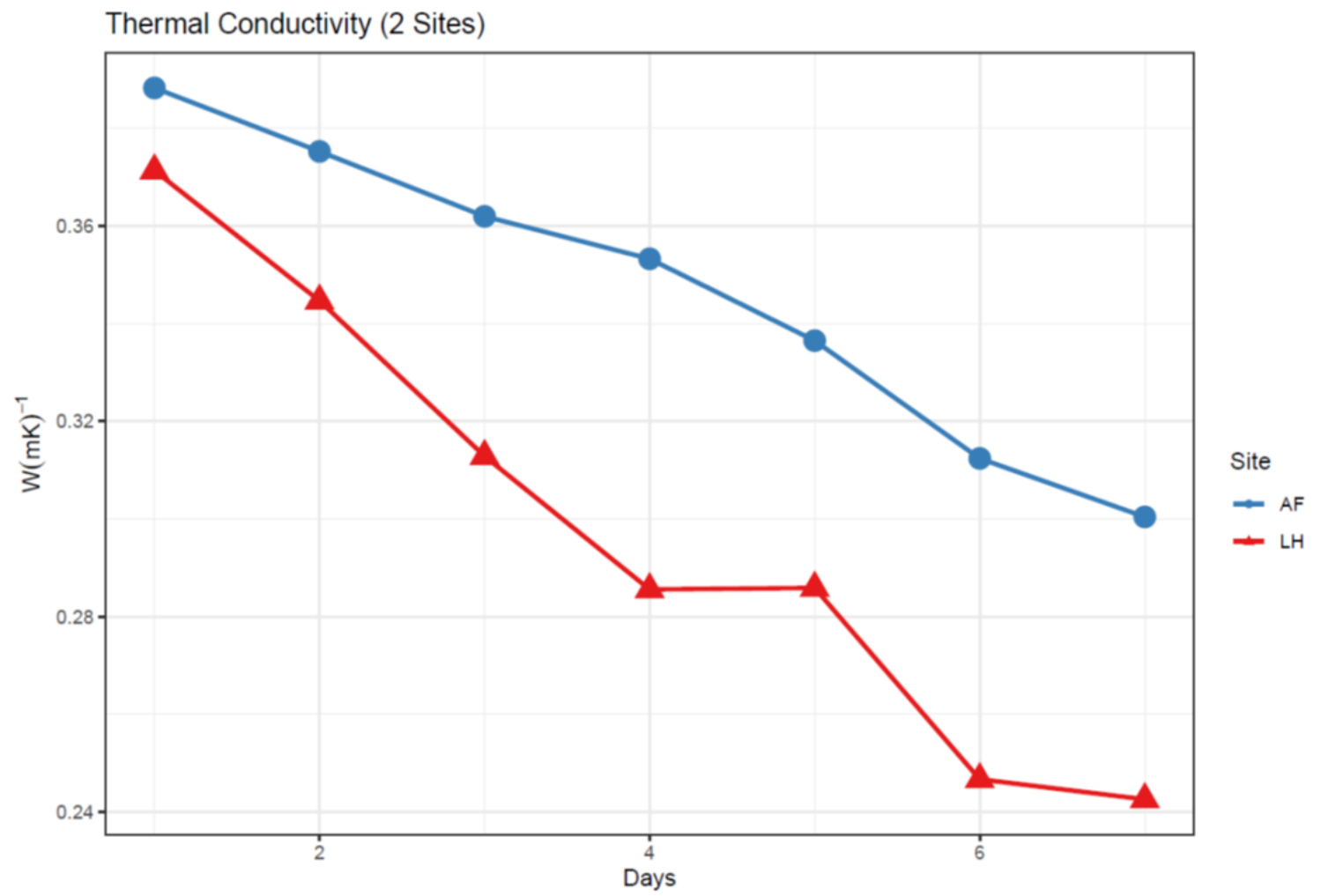

Figure 10. Thermal conductivity $\left(\mathrm{W}\left(\mathrm{m}^{*} \mathrm{~K}\right)^{-1}\right)$ for two sites on Ardley Island over seven days. Sites were found to be significantly different $(\mathrm{F}=56.053, \mathrm{P}<0.001)$. LH (Lighthouse) represents high tissue nitrogen and AF (Ardley Far) represents low tissue nitrogen. Polytrichastrum alpinum, Sanionia georgicouncinata, and Chorisodontium aciphyllum were included in each site. 


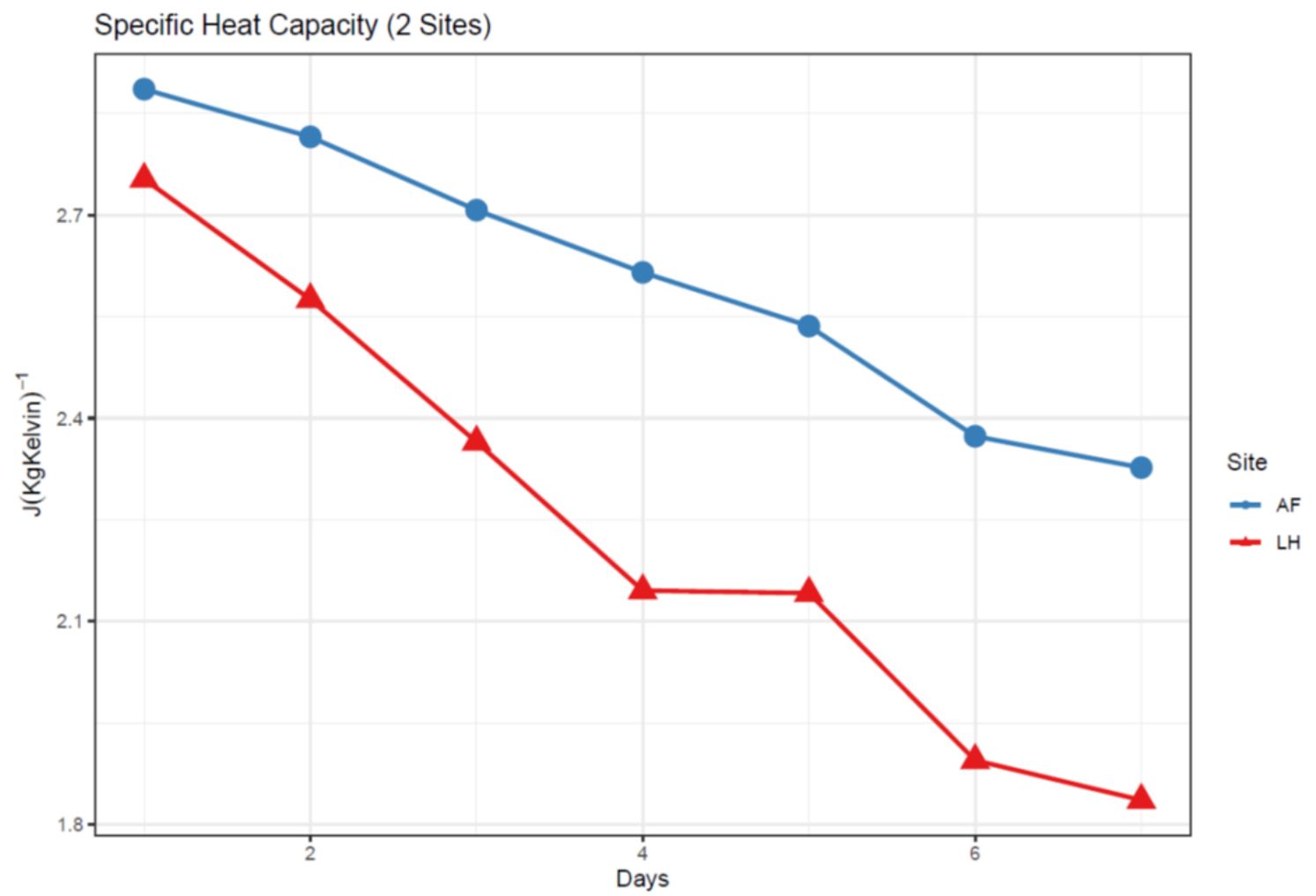

Figure 11. Specific heat capacity $\left(\mathrm{J}\left(\mathrm{Kg}^{*} \mathrm{~K}\right)^{-1}\right)$ for two sites on Ardley Island over seven days. Sites were found to be significantly different $(F=45.578, P<0.001)$. LH (Lighthouse) represents high tissue nitrogen and AF (Ardley Far) represents low tissue nitrogen. Polytrichastrum alpinum, Sanionia georgicouncinata, and Chorisodontium aciphyllum were included in each site. 


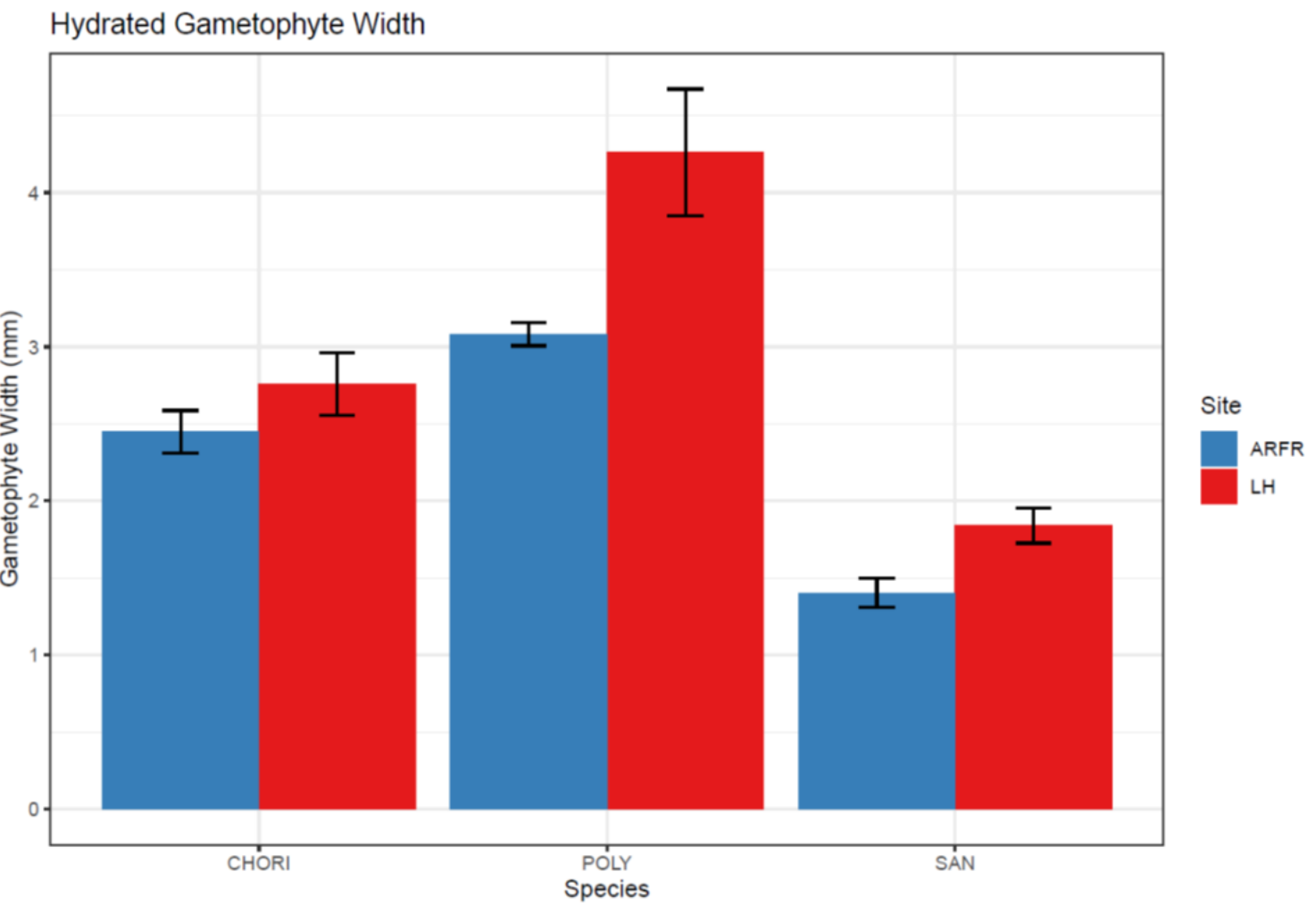

Figure 12. Average width of hydrated moss gametophytes (mm) across three species and two sites on Ardley Island. Each gametophyte was blotted dry and measured at its widest point. LH (Lighthouse) represents high tissue nitrogen and AF (Ardley Far) represents low tissue nitrogen. $\mathrm{CHORI}=$ Chorisodontium aciphyllum, $\mathrm{POLY}=$ Polytrichastrum alpinum, and SAN = Sanionia georgicouncinata . 


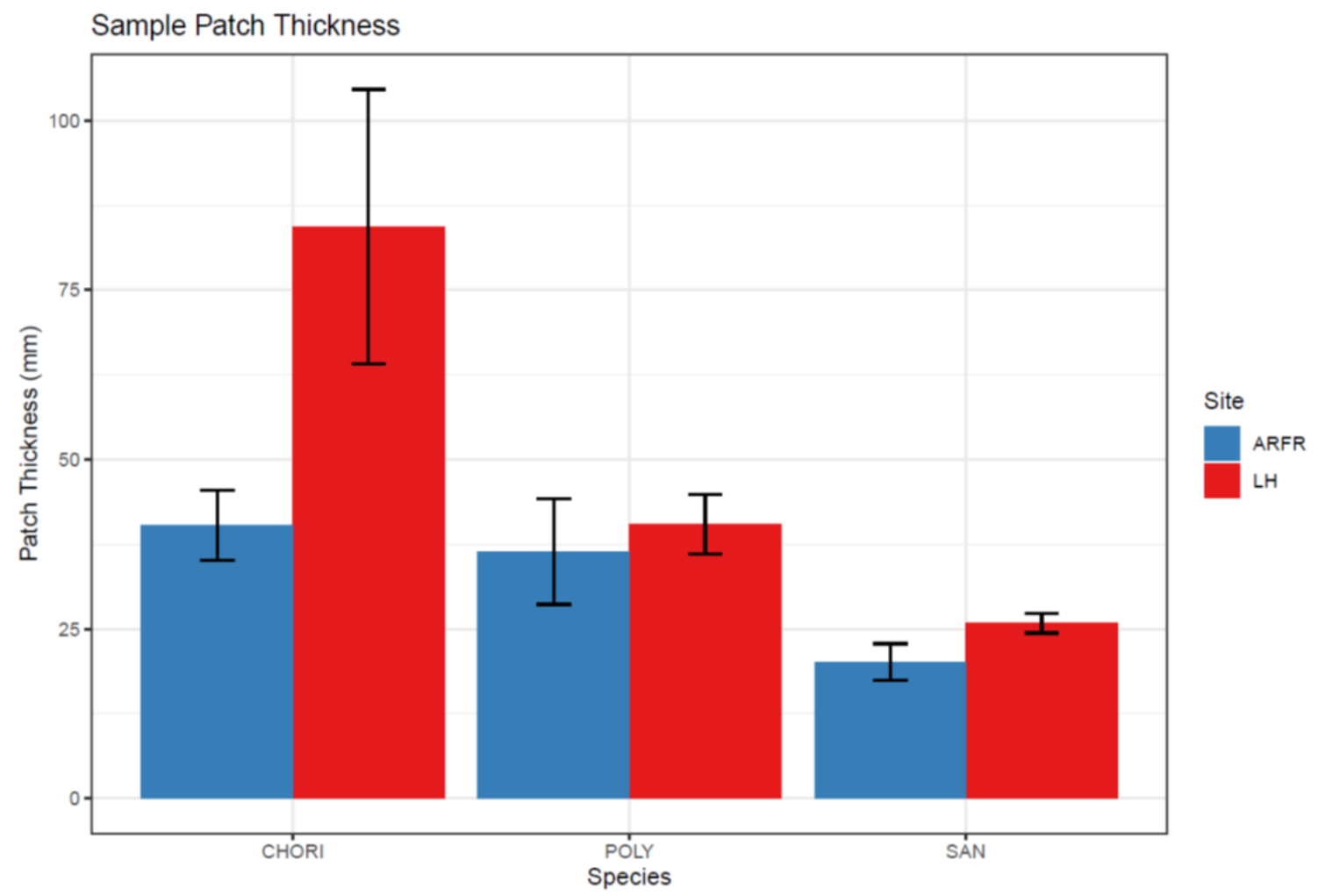

Figure 13. Average thickness of moss patches across three species and two sites. All patches were hydrated prior to measuring. LH (Lighthouse) represents high tissue nitrogen and AF (Ardley Far) represents low tissue nitrogen. CHORI = Chorisodontium aciphyllum, POLY = Polytrichastrum alpinum, and SAN = Sanionia georgicouncinata . 


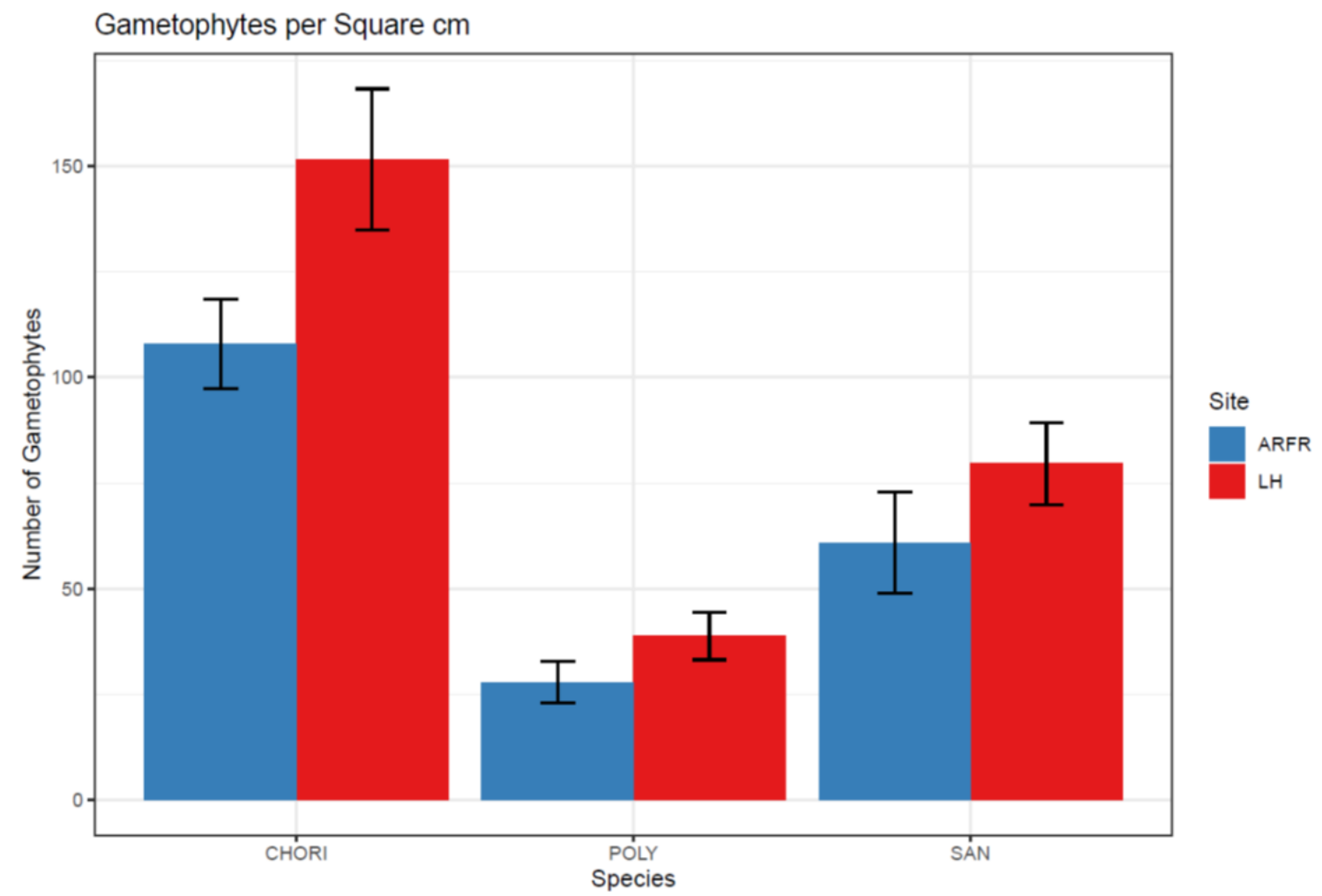

Figure 14. Average number of moss gametophytes per square centimeter. Gametophytes were counted from subsampled cores $13 \mathrm{~mm}$ in diameter and scaled to square centimeter. LH (Lighthouse) represents high tissue nitrogen and AF (Ardley Far) represents low tissue nitrogen. $\mathrm{CHORI}=$ Chorisodontium aciphyllum, $\mathrm{POLY}=$ Polytrichastrum alpinum, and SAN = Sanionia georgicouncinata . 


\section{References}

Allison, J. S., and R. I. L. Smith. 1973. The Vegetation of Elephant Island, South Shetland Islands. BAS Bulletin 33\&34:185-212.

Amesbury, M. J., T. P. Roland, J. Royles, D. A. Hodgson, P. Convey, H. Griffiths, and D. J. Charman. 2017. Widespread Biological Response to Rapid Warming on the Antarctic Peninsula. Current Biology 27:1616-1622.

Arndt, D. S., H. J. Diamond, A. J. Dolman, R. L. Fogt, M. C. Gregg, B. D. Hall, and M. O. Jeffries. 2013. State of the climate in 2012. Bulletin of the American Meteorological Society 94:S1-S238.

Australian Antarctic Division. 2021. Australian Antarctic Data Centre. data.aad.gov.au.

Bakatovich, A., and F. Gaspar. 2019. Composite material for thermal insulation based on moss raw material. Construction and Building Materials 228.

Ball, B. A., and R. A. Virginia. 2014. The ecological role of moss in a polar desert: Implications for aboveground-belowground and terrestrial-aquatic linkages. Polar Biology 37:651-664.

Bardgett, R. D., and L. R. Walker. 2004. Impact of coloniser plant species on the development of decomposer microbial communities following deglaciation. Soil Biology and Biochemistry 36:555-559.

Beringer, J., A. H. Lynch, F. S. I. Chapin, M. Mack, and G. B. Bonan. 2001. The representation of arctic soils in the land surface model: The importance of mosses. Journal of Climate 14:3324-3335.

Bjorck, S. 1991. Stratigraphic and paleoclimatic studies of a 5500-year-old moss bank on Elephant Island, Antarctica. Arctic \& Alpine Research 23:361-374.

Blok, D., M. M. P. D. Heijmans, G. Schaepman-Strub, J. van Ruijven, F. J. W. Parmentier, T. C. Maximov, and F. Berendse. 2011. The Cooling Capacity of Mosses: Controls on Water and Energy Fluxes in a Siberian Tundra Site. Ecosystems 14:1055-1065.

Bokhorst, S., and P. Convey. 2016. Impact of marine vertebrates on Antarctic terrestrial micro-arthropods. Antarctic Science 28:175-186.

Bokhorst, S., P. Convey, and R. Aerts. 2019. Nitrogen Inputs by Marine Vertebrates Drive Abundance and Richness in Antarctic Terrestrial Ecosystems. Current Biology 29:1721-1727.e3.

Bokhorst, S., A. Huiskes, P. Convey, and R. Aerts. 2007. The effect of environmental change on vascular plant and cryptogam communities from the Falkland Islands and the Maritime Antarctic. BMC Ecology 7. 
Bowler, D. E., L. Buyung-Ali, T. M. Knight, and A. S. Pullin. 2010. Urban greening to cool towns and cities: A systematic review of the empirical evidence. Landscape and Urban Planning 97:147-155.

Boy, J., R. Godoy, O. Shibistova, D. Boy, R. McCulloch, A. A. De La Fuente, M. A. Morales, R. Mikutta, and G. Guggenberger. 2016. Successional patterns along soil development gradients formed by glacier retreat in the Maritime Antarctic, King George Island. Revista Chilena de Historia Natural 89.

Bracegirdle, T. J., W. M. Connolley, and J. Turner. 2008. Antarctic climate change over the twenty first century. Journal of Geophysical Research Atmospheres 113.

Bromwich, D. H., J. P. Nicolas, A. J. Monaghan, M. A. Lazzara, L. M. Keller, G. A. Weidner, and A. B. Wilson. 2013. Central West Antarctica among the most rapidly warming regions on Earth. Nature Geoscience 6:139-145.

Brunner, I., and S. Brodbeck. 2001. Response of mycorrhizal Norway spruce seedlings to various nitrogen loads and sources. Environmental Pollution 114:223-233.

Cannone, N., G. Diolaiuti, M. Guglielmin, and C. Smiraglia. 2008. Accelerating climate change impacts on alpine glacier forefield ecosystems in the European Alps. Ecological Applications 18:637-648.

Cannone, N., M. D. Fratte, P. Convey, M. R. Worland, and M. Guglielmin. 2017. Ecology of moss banks on Signy Island (maritime Antarctic). Botanical Journal of the Linnean Society 184:518-533.

Cannone, N., and M. Guglielmin. 2009. Influence of vegetation on the ground thermal regime in continental Antarctica. Geoderma 151:215-223.

Castle, S. C., Y. Lekberg, D. Affleck, and C. C. Cleveland. 2016. Soil abiotic and biotic controls on plant performance during primary succession in a glacial landscape. Journal of Ecology 104:1555-1565.

Chapin, F. S., G. R. Shaver, A. E. Giblin, K. J. Nadelhoffer, and J. A. Laundre. 1995. Responses of Arctic Tundra to Experimental and Observed Changes in Climate. Ecology 76:694-711.

Cook, A. J., A. J. Fox, D. G. Vaughan, and J. G. Ferrigno. 2005. Retreating glacier fronts on the Antarctic Peninsula over the past half-century. Science 308:541-544.

Cornelissen, J. H. C., S. I. Lang, N. A. Soudzilovskaia, and H. J. During. 2007. Comparative cryptogam ecology: A review of bryophyte and lichen traits that drive biogeochemistry. Annals of Botany 99:987-1001.

Corscadden, K. W., J. N. Biggs, and D. K. Stiles. 2014. Sheep's wool insulation: A sustainable alternative use for a renewable resource? Resources, Conservation and Recycling 86:9-15.

Davison, J., D. García de León, M. Zobel, M. Moora, C. G. Bueno, M. Barceló, M. Gerz, 
D. León, Y. Meng, V. D. Pillar, S. K. Sepp, N. A. Soudzilovaskaia, L. Tedersoo, S. Vaessen, T. Vahter, B. Winck, and M. Öpik. 2020. Plant functional groups associate with distinct arbuscular mycorrhizal fungal communities. New Phytologist 226:1117-1128.

Day, T. A., C. T. Ruhland, and F. S. Xiong. 2008. Warming increases aboveground plant biomass and $\mathrm{C}$ stocks in vascular-plant-dominated Antarctic tundra. Global Change Biology 14:1827-1843.

Deakova, T. 2019. Isoprene emission in Polytrichaceae mosses. Portland State University.

Deeming, D. C., A. M. Dickinson, R. E. Broughton, E. Locke, L. A. Gray, S. L. Bennett, R. Gilchrist, S. Muniz, A. M. Goodman, and L. E. Biddle. 2020. Factors Affecting Thermal Insulation of Songbird Nests as Measured Using Temperature Loggers. Physiological and Biochemical Zoology 93:488-504.

Ding, L., Z. Lu, L. Gao, S. Guo, and Q. Shen. 2018. Is nitrogen a key determinant of water transport and photosynthesis in higher plants upon drought stress? Frontiers in Plant Science 9:1-12.

Ehrenfeld, J. G., B. Ravit, and K. Elgersma. 2005. Feedback in the plant-soil system. Annual Review of Environment and Resources 30:75-115.

Evans, J. R., and V. C. Clarke. 2019. The nitrogen cost of photosynthesis. Journal of Experimental Botany 70:7-15.

Eviner, V. T., and F. S. Chapin III. 2003. Functional matrix: A conceptual framework for predicting multiple plant effects on ecosystem processes. Annual Review of Ecology, Evolution, and Systematics 34:455-485.

Fan, X. Y., W. Y. Liu, L. Song, S. Liu, X. M. Shi, and G. Di Yuan. 2020. A combination of morphological and photosynthetic functional traits maintains the vertical distribution of bryophytes in a subtropical cloud forest. American Journal of Botany 107:761-772.

Favero-Longo, S. E., M. R. Worland, P. Convey, R. I. L. Smith, R. Piervittori, M. Guglielmin, and N. Cannone. 2012. Primary succession of lichen and bryophyte communities following glacial recession on Signy Island, South Orkney Islands, Maritime Antarctic. Antarctic Science 24:323-336.

Fountain, A. G., G. Saba, B. Adams, P. Doran, W. Fraser, M. Gooseff, M. Obryk, J. C. Priscu, S. Stammerjohn, and R. A. Virginia. 2016. The Impact of a Large-Scale Climate Event on Antarctic Ecosystem Processes. BioScience 66:848-863.

De Frenne, P., J. Lenoir, M. Luoto, B. R. Scheffers, F. Zellweger, J. Aalto, M. B. Ashcroft, D. M. Christiansen, G. Decocq, K. De Pauw, S. Govaert, C. Greiser, E. Gril, A. Hampe, T. Jucker, D. H. Klinges, I. A. Koelemeijer, J. J. Lembrechts, R. Marrec, C. Meeussen, J. Ogée, V. Tyystjärvi, P. Vangansbeke, and K. Hylander. 
2021. Forest microclimates and climate change: Importance, drivers and future research agenda. Global Change Biology:1-19.

Freund, S. M., B. A. Newingham, J. C. Chambers, A. K. Urza, B. A. Roundy, and J. H. Cushman. 2021. Plant functional groups and species contribute to ecological resilience a decade after woodland expansion treatments. Ecosphere 12:1-24.

Gavazov, K. S., N. A. Soudzilovskaia, R. S. P. van Logtestijn, M. Braster, and J. H. C. Cornelissen. 2010. Isotopic analysis of cyanobacterial nitrogen fixation associated with subarctic lichen and bryophyte species. Plant and Soil 333:507-517.

Gentle, A. R., J. L. C. Aguilar, and G. B. Smith. 2011. Optimized cool roofs: Integrating albedo and thermal emittance with R-value. Solar Energy Materials and Solar Cells 95:3207-3215.

Gornall, J. L., I. S. Jónsdóttir, S. J. Woodin, and R. Van Der Wal. 2007. Arctic mosses govern below-ground environment and ecosystem processes. Oecologia 153:931941.

Green, T. G. A., R. D. Seppelt, L. R. Brabyn, C. Beard, R. Türk, and O. L. Lange. 2015. Flora and vegetation of Cape Hallett and vicinity, northern Victoria Land, Antarctica. Polar Biology 38:1825-1845.

Hespanhol, H., G. Fabón, L. Monforte, J. Martínez-Abaigar, and E. Núñez-Olivera. 2014. Among- and within-genus variability of the UV-absorption capacity in saxicolous mosses. The Bryologist 117:1-9.

Hofhansl, F., E. Chacón-Madrigal, ̊̊. Brännström, U. Dieckmann, and O. Franklin. 2021. Mechanisms driving plant functional trait variation in a tropical forest. Ecology and Evolution:1-15.

Kennedy, A. D. 1995. Antarctic terrestrial ecosystem response to global environmental change. Annual Review of Ecology and Systematics 26:683-704.

Kleier, C., and P. Rundel. 2009. Energy balance and temperature relations of Azorella compacta, a high-elevation cushion plant of the central Andes. Plant Biology 11:351-358.

Kleinen, T., and V. Brovkin. 2018. Pathway-dependent fate of permafrost region carbon. Environmental Research Letters 13.

Knelman, J. E., T. M. Legg, S. P. O’Neill, C. L. Washenberger, A. González, C. C. Cleveland, and D. R. Nemergut. 2012. Bacterial community structure and function change in association with colonizer plants during early primary succession in a glacier forefield. Soil Biology and Biochemistry 46:172-180.

Kośny, J., and D. W. Yarbrough. 2017. 4.10 Thermal Bridges in Building Structures. Page in R. P. Chhabra, editor. CRC Handbook of Thermal Engineering. Second ed. CRC Press, Boca Raton, FL. 
Laine, A. M., T. Lindholm, M. Nilsson, O. Kutznetsov, V. E. J. Jassey, and E. S. Tuittila. 2021. Functional diversity and trait composition of vascular plant and Sphagnum moss communities during peatland succession across land uplift regions. Journal of Ecology:1774-1789.

Lee, Y. Il, H. S. Lim, and H. Il Yoon. 2009. Carbon and nitrogen isotope composition of vegetation on King George Island, maritime Antarctic. Polar Biology 32:1607-1615.

Lepane, V., K. Künnis-Beres, E. Kaup, and B. Sharma. 2018. Dissolved organic matter, nutrients, and bacteria in Antarctic soil core from Schirmacher Oasis. Journal of Soils and Sediments 18:2715-2726.

Li, S., B. Xiao, F. Sun, and G. J. Kidron. 2021. Moss-dominated biocrusts enhance water vapor sorption capacity of surface soil and increase non-rainfall water deposition in drylands. Geoderma 388.

Liu, B. Y., C. Y. Lei, J. H. Jin, Y. Y. Guan, S. Li, Y. S. Zhang, and W. Q. Liu. 2016. Physiological responses of two moss species to the combined stress of water deficit and elevated $\mathrm{N}$ deposition (II): Carbon and nitrogen metabolism. Ecology and Evolution 6:7596-7609.

Lloyd, J., and J. Taylor. 1994. On the Temperature Dependence of Soil Respiration. Functional ecology 8:315-323.

Manninen, S., C. Woods, I. D. Leith, and L. J. Sheppard. 2011. Physiological and morphological effects of long-term ammonium or nitrate deposition on the green and red (shade and open grown) Sphagnum capillifolium. Environmental and Experimental Botany 72:140-148.

Nerem, R. S., B. D. Beckley, J. T. Fasullo, B. D. Hamlington, D. Masters, and G. T. Mitchum. 2018. Climate-change-driven accelerated sea-level rise detected in the altimeter era. Proceedings of the National Academy of Sciences of the United States of America 115:2022-2025.

Van Nes, E. H., M. Scheffer, V. Brovkin, T. M. Lenton, H. Ye, E. Deyle, and G. Sugihara. 2015. Causal feedbacks in climate change. Nature Climate Change 5:445448.

O’Donnell, J. A., V. E. Romanovsky, J. W. Harden, and A. D. McGuire. 2009. The effect of moisture content on the thermal conductivity of moss and organic soil horizons from black spruce ecosystems in interior Alaska. Soil Science 174:646-651.

Ochyra, R., R. Lewis-Smith, and H. Bednarek-Ochyra. 2008. Illustrated moss flora of Antarctica. First. Cambridge University Press.

Olech, M., and A. Słaby. 2016. Changes in the lichen biota of the Lions Rump area, King George Island, Antarctica, over the last 20 years. Polar Biology 39:1499-1503.

Park, J. H., T. A. Day, S. Strauss, and C. T. Ruhland. 2007. Biogeochemical pools and fluxes of carbon and nitrogen in a maritime tundra near penguin colonies along the 
Antarctic Peninsula. Polar Biology 30:199-207.

Pearson, R. G., S. J. Phillips, M. M. Loranty, P. S. A. Beck, T. Damoulas, S. J. Knight, and S. J. Goetz. 2013. Shifts in Arctic vegetation and associated feedbacks under climate change. Nature Climate Change 3:673-677.

Porada, P., A. Ekici, and C. Beer. 2016. Effects of bryophyte and lichen cover on permafrost soil temperature at large scale. Cryosphere 10:2291-2315.

Potapowicz, J., D. Szumińska, M. Szopińska, and Ż. Polkowska. 2018. The influence of global climate change on the environmental fate of anthropogenic pollution released from the permafrost: Part I. Case study of Antarctica. Science of the Total Environment 651:1534-1548.

Prather, H. M., A. Casanova-Katny, A. F. Clements, M. W. Chmielewski, M. A. Balkan, E. E. Shortlidge, T. N. Rosenstiel, and S. M. Eppley. 2019. Species-specific effects of passive warming in an Antarctic moss system. Royal Society Open Science 6.

Proctor, M. C. F., and N. Smirnoff. 2015. Photoprotection in bryophytes: rate and extent of dark relaxation of non-photochemical quenching of chlorophyll fluorescence. Journal of Bryology 37:171-177.

Putzke, J., and A. B. Pereira. 2001. The Ancarctic Mosses: With Special Reference to the South Shetland Islands. Universidade Luterana do Brasil. ULBRA.

Quesada, C. A., O. L. Phillips, M. Schwarz, C. I. Czimczik, T. R. Baker, S. Patiño, N. M. Fyllas, M. G. Hodnett, R. Herrera, S. Almeida, E. Alvarez Dávila, A. Arneth, L. Arroyo, K. J. Chao, N. Dezzeo, T. Erwin, A. Di Fiore, N. Higuchi, E. Honorio Coronado, E. M. Jimenez, T. Killeen, A. T. Lezama, G. Lloyd, G. Löpez-González, F. J. Luizão, Y. Malhi, A. Monteagudo, D. A. Neill, P. Núñez Vargas, R. Paiva, J. Peacock, M. C. Peñuela, A. Peña Cruz, N. Pitman, N. Priante Filho, A. Prieto, H. Ramírez, A. Rudas, R. Salomão, A. J. B. Santos, J. Schmerler, N. Silva, M. Silveira, R. Vásquez, I. Vieira, J. Terborgh, and J. Lloyd. 2012. Basin-wide variations in Amazon forest structure and function are mediated by both soils and climate. Biogeosciences 9:2203-2246.

Razaq, M., P. Zhang, H. L. Shen, and Salahuddin. 2017. Influence of nitrogen and phosphorous on the growth and root morphology of Acer mono. PLoS ONE 12:114.

Rice, S. K., L. Aclander, and D. T. Hanson. 2008. Do bryophyte shoot systems function like vascular plant leaves or canopies? Functional trait relationships in Sphagnum mosses (Sphagnaceae). American Journal of Botany 95:1366-1374.

Rice, S. K., D. Collins, and A. M. Anderson. 2001. Functional significance of variation in bryophyte canopy structure. American Journal of Botany 88:1568-1576.

Rice, S. K., T. A. Gagliardi, and R. A. Krasa. 2018. Canopy structure affects temperature distributions and free convection in moss shoot systems. American Journal of 
Botany 105:1499-1511.

Roberts, E. H. 1988. Temperature and seed germination. Symposia of the Society for Experimental Biology 42:109-132.

Robinson, S. I., J. Mikola, O. Ovaskainen, and E. J. O'Gorman. 2021. Temperature effects on the temporal dynamics of a subarctic invertebrate community. Journal of Animal Ecology:1-11.

Rudolph, E. 1965. Antarctic lichens and vascular plants: their significance. BioScience 15:285-287.

Ruuska, T., J. Vinha, and H. Kivioja. 2017. Measuring thermal conductivity and specific heat capacity values of inhomogeneous materials with a heat flow meter apparatus. Journal of Building Engineering 9:135-141.

Samui, G., R. Antony, and M. Thamban. 2020. Fate of Dissolved Organic Carbon in Antarctic Surface Environments During Summer. Journal of Geophysical Research: Biogeosciences 125:1-14.

van der Sande, M. T., E. J. M. M. Arets, M. Peña-Claros, M. R. Hoosbeek, Y. CáceresSiani, P. van der Hout, and L. Poorter. 2018. Soil fertility and species traits, but not diversity, drive productivity and biomass stocks in a Guyanese tropical rainforest. Functional Ecology 32:461-474.

Sanz Pérez, V., P. Castro Díez, and F. Valladares. 2007. Growth versus storage: Responses of Mediterranean oak seedlings to changes in nutrient and water availabilities. Annals of Forest Science 64:201-210.

Schmidt, S. K., D. Porazinska, B. L. Concienne, J. L. Darcy, A. J. King, and D. R. Nemergut. 2016. Biogeochemical Stoichiometry Reveals P and N Limitation Across the Post-glacial Landscape of Denali National Park, Alaska. Ecosystems 19:11641177.

Shortlidge, E. E., S. M. Eppley, H. Kohler, T. N. Rosenstiel, G. E. Zúñiga, and A. Casanova-Katny. 2017. Passive warming reduces stress and shifts reproductive effort in the Antarctic moss, Polytrichastrum alpinum. Annals of Botany 119:27-38.

Smith, R. I. L. 1981. Types of peat forming veg from South Georgia. British Antarctic Survey Bulletin 53:119-139.

Smith, R. J., J. C. Benavides, S. Jovan, M. Amacher, and B. McCune. 2015. A rapid method for landscape assessment of carbon storage and ecosystem function in moss and lichen ground layers. The Bryologist 118:32-45.

Soudzilovskaia, N. A., P. M. van Bodegom, and J. H. C. Cornelissen. 2013. Dominant bryophyte control over high-latitude soil temperature fluctuations predicted by heat transfer traits, field moisture regime and laws of thermal insulation. Functional Ecology 27:1442-1454. 
Stoy, P. C., L. E. Street, A. V. Johnson, A. Prieto-Blanco, and S. A. Ewing. 2012.

Temperature, heat flux, and reflectance of common subarctic mosses and lichens under field conditions: Might changes to community composition impact climaterelevant surface fluxes? Arctic, Antarctic, and Alpine Research 44:500-508.

Strauss, S. L., C. T. Ruhl, and T. A. Day. 2009. Trends in soil characteristics along a recently deglaciated foreland on Anvers Island, Antarctic Peninsula. Polar Biology 32:1779-1788.

Thomas, H. J. D., I. H. Myers-Smith, A. D. Bjorkman, S. C. Elmendorf, D. Blok, J. H. C. Cornelissen, B. C. Forbes, R. D. Hollister, S. Normand, J. S. Prevéy, C. Rixen, G. Schaepman-Strub, M. Wilmking, S. Wipf, W. K. Cornwell, J. Kattge, S. J. Goetz, K. C. Guay, J. M. Alatalo, A. Anadon-Rosell, S. Angers-Blondin, L. T. Berner, R. G. Björk, A. Buchwal, A. Buras, M. Carbognani, K. Christie, L. Siegwart Collier, E. J. Cooper, A. Eskelinen, E. R. Frei, O. Grau, P. Grogan, M. Hallinger, M. M. P. D. Heijmans, L. Hermanutz, J. M. G. Hudson, K. Hülber, M. Iturrate-Garcia, C. M. Iversen, F. Jaroszynska, J. F. Johnstone, E. Kaarlejärvi, A. Kulonen, L. J. Lamarque, E. Lévesque, C. J. Little, A. Michelsen, A. Milbau, J. Nabe-Nielsen, S. S. Nielsen, J. M. Ninot, S. F. Oberbauer, J. Olofsson, V. G. Onipchenko, A. Petraglia, S. B. Rumpf, P. R. Semenchuk, N. A. Soudzilovskaia, M. J. Spasojevic, J. D. M. Speed, K. D. Tape, M. te Beest, M. Tomaselli, A. Trant, U. A. Treier, S. Venn, T. Vowles, S. Weijers, T. Zamin, O. K. Atkin, M. Bahn, B. Blonder, G. Campetella, B. E. L. Cerabolini, F. S. Chapin, M. Dainese, F. T. de Vries, S. Díaz, W. Green, R. B. Jackson, P. Manning, Niinemets, W. A. Ozinga, J. Peñuelas, P. B. Reich, B. Schamp, S. Sheremetev, and P. M. van Bodegom. 2019. Traditional plant functional groups explain variation in economic but not size-related traits across the tundra biome. Global Ecology and Biogeography 28:78-95.

Thomazini, A., E. S. Mendonça, D. B. Teixeira, I. C. C. Almeida, N. La Scala, L. P. Canellas, K. A. Spokas, D. M. B. P. Milori, C. V. G. Turbay, R. B. A. Fernandes, and C. E. G. R. Schaefer. 2015. CO2 and $\mathrm{N} 2 \mathrm{O}$ emissions in a soil chronosequence at a glacier retreat zone in Maritime Antarctica. Science of the Total Environment 521-522:336-345.

Turetsky, M. R., B. Bond-Lamberty, E. Euskirchen, J. Talbot, S. Frolking, A. D. McGuire, and E. S. Tuittila. 2012. The resilience and functional role of moss in boreal and arctic ecosystems. New Phytologist 196:49-67.

Turner, J., N. E. Barrand, T. J. Bracegirdle, P. Convey, D. A. Hodgson, M. Jarvis, A. Jenkins, G. Marshall, M. P. Meredith, H. Roscoe, J. Shanklin, J. French, H. Goosse, M. Guglielmin, J. Gutt, S. Jacobs, M. C. Kennicutt, V. Masson-Delmotte, P. Mayewski, F. Navarro, S. Robinson, T. Scambos, M. Sparrow, C. Summerhayes, K. Speer, and A. Klepikov. 2014. Antarctic climate change and the environment: An update. Polar Record 50:237-259.

Vaughan, D. G., and C. S. M. Doake. 1996. Recent atmospheric warming and retreat of ice shelves on the Antarctic Peninsula. Nature 379:328-331. 
Velicogna, I., Y. Mohajerani, A. Geruo, F. Landerer, J. Mouginot, B. Noel, E. Rignot, T. Sutterley, M. van den Broeke, M. van Wessem, and D. Wiese. 2020. Continuity of Ice Sheet Mass Loss in Greenland and Antarctica From the GRACE and GRACE Follow-On Missions. Geophysical Research Letters 47:1-8.

Wallenstein, M. D., S. K. Mcmahon, and J. P. Schimel. 2009. Seasonal variation in enzyme activities and temperature sensitivities in Arctic tundra soils. Global Change Biology 15:1631-1639.

Wang, P., L. D’Imperio, E. M. Biersma, R. Ranniku, W. Xu, Q. Tian, P. Ambus, and B. Elberling. 2020. Combined effects of glacial retreat and penguin activity on soil greenhouse gas fluxes on South Georgia, sub-Antarctica. Science of the Total Environment 718.

Wasley, J., S. A. Robinson, C. E. Lovelock, and M. Popp. 2006. Climate change manipulations show Antarctic flora is more strongly affected by elevated nutrients than water. Global Change Biology 12:1800-1812.

Xiao, B., and M. A. Bowker. 2020. Moss-biocrusts strongly decrease soil surface albedo, altering land-surface energy balance in a dryland ecosystem. Science of the Total Environment 741.

Yue, Y., H. Liu, J. Xue, Y. Li, and W. Guo. 2020. Ecological indicators of near-surface permafrost habitat at the southern margin of the boreal forest in China. Ecological Indicators 108. 